Division of Geological \& Geophysical Surveys

PRELIMINARY INTERPRETIVE REPORT 2008-3d

\title{
ACTIVE AND POTENTIALLY ACTIVE FAULTS IN OR NEAR THE ALASKA HIGHWAY CORRIDOR, DELTA JUNCTION TO DOT LAKE, ALASKA
}

by

Gary A. Carver, Sean P. Bemis, Diana N. Solie, and Kyle E. Obermiller

December 2008

THIS REPORT HAS NOT BEEN REVIEWED FOR TECHNICAL CONTENT (EXCEPT AS NOTED IN TEXT) OR FOR CONFORMITY TO THE EDITORIAL STANDARDS OF DGGS.

Released by

STATE OF ALASKA

DEPARTMENT OF NATURAL RESOURCES

Division of Geological \& Geophysical Surveys 3354 College Rd.

Fairbanks, Alaska 99709-3707 



\section{CONTENTS}

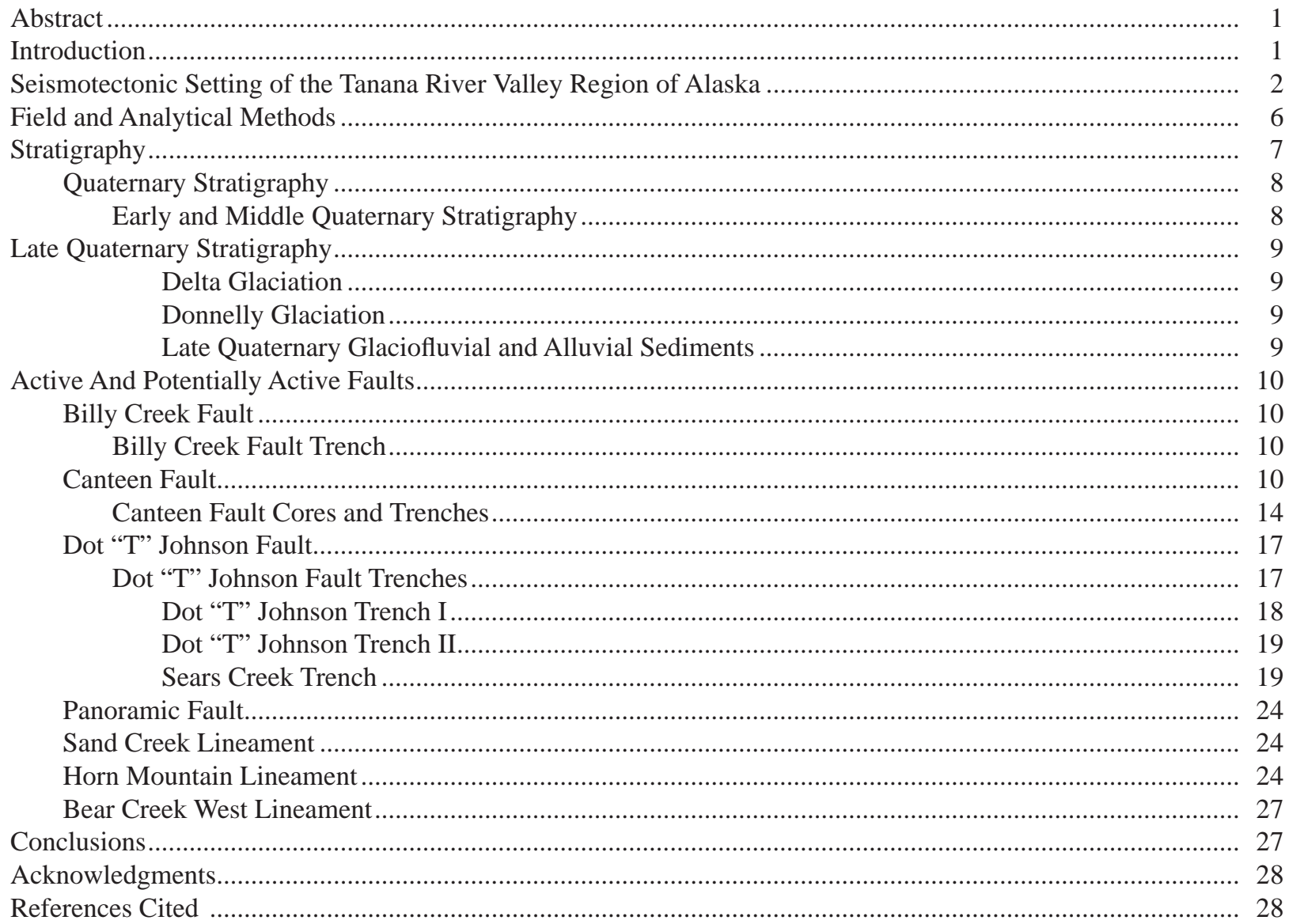

\section{FIGURES}

Figure 1. Map of the Alaska Highway corridor.

2. Map showing upper crustal seismic activity and principal faults in the Alaska Highway Corridor study area ....

3. Map showing active and potentially active faults in and near Alaska Highway corridor study area ..... 5

4. Map showing middle and late Tertiary sediments of the Usibelli Group and Nenana Gravel and exhumed middle Tertiary surfaces that serve as distinctive markers in interpreting post-Tertiary deformation in the study area.

5. Oblique aerial photograph of the Billy Creek fault at the trench site ............................................ 11

6. Scarp profiles on the Billy Creek fault at the trench site ...................................................... 11

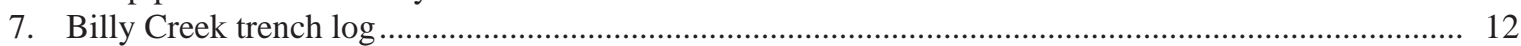

8. Oblique air photograph looking to the northwest of Donnelly- and Delta-age moraines offset by the Canteen fault on the west side of the Little Gerstle River valley ................................................... 13

9. Sketch map showing the locations of the trench and the array of cores across the Canteen fault.......... 14

10. Stratigraphy of the marsh and pond margin across the Canteen fault at the offset Donnelly moraine... 15

11. Log of a small trench across the Canteen fault at the offset moraine site........................................ 16

12. Electromagnetic map (EM), 140,000 Hz, of the corridor with the Dot "T" Johnson, Panoramic, and Canteen faults and the Sand Creek, Horn Mountain, Saddle, and Billy Creek lineament.................... 17

13. Profiles of the deformed Tanana River terrace and the floor of Sam Creek valley and the structural model for the pop-up thrust wedge on the Dot “T” Johnson fault at trench site I ............................. 18

14. Photo showing the "mole track" scarp on the Dot “T”" Johnson fault at trench I, viewed looking east. 19 
15. Log of the west wall of trench I across the Dot "T" Johnson fault with an enlarged section at the fault

16. Log showing east wall of trench I across the Dot "T” Johnson fault, showing the same fault pattern as the west wall. The trench was hand-dug across the mole track ridge ..................................... 21

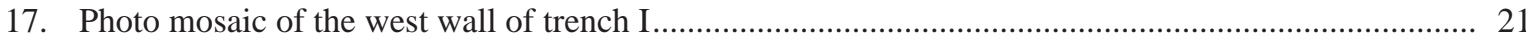

18. Log of the west wall of trench II on the Dot "T" Johnson fault ............................................................ 22

19. Photograph of the west wall of trench II on the Dot "T" Johnson fault ................................................. 22

20. Logs of the Sears Creek trench on the Dot "T" Johnson fault............................................................ 23

21. Cross-section showing a measured scarp profile, trench, and adjacent highway road cut at the

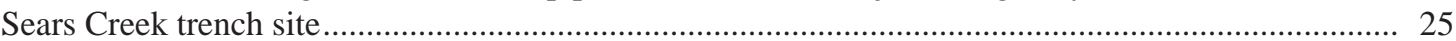

22. Color infrared vertical air photo showing the trace of the Panoramic fault............................................. 25

23. Photo showing the prominent vegetation line on the Sand Creek lineament in the central part of the Sand Creek valley viewed from the south ..................................................................................... 26

24. Oblique air photo and surveyed profile across a scarp-like feature along the Sand Creek lineament.... 26

25. Photograph looking northeast along the scarp-like feature shown in figure 24 .

\section{TABLE}

Table 1. Location of trenches, core sites, and scarp profiles in the Alaska Highway Corridor, Mount Hayes and Tanacross quadrangles, Alaska

\section{APPENDIX}

Radiocarbon analytical results from Beta Analytic Inc. For samples collected on the Alaska Highway corridor, Mount Hayes and Tanacross quadrangles

\section{Note: This RePort (INCLUDiNg ALl ANALYTICAL DATA AND TABLES) IS AVAILABLE IN DIGITAL FORMAT FROM THE DGGS WEBSITE (http://www.dggs.dnr.state.ak.us) AT NO CHARGE.}




\title{
ACTIVE AND POTENTIALLY ACTIVE FAULTS IN OR NEAR THE ALASKA HIGHWAY CORRIDOR, DELTA JUNCTION TO DOT LAKE, ALASKA
}

\author{
by \\ Gary A. Carver, ${ }^{1}$ Sean P. Bemis,, ${ }^{2,3}$ Diana N. Solie, ${ }^{2}$ and Kyle E. Obermiller ${ }^{2,4}$
}

\begin{abstract}
In 2005 the Alaska Division of Geological \& Geophysical Surveys initiated a multi-year geologic project focused on a corridor along the Alaska Highway between Delta Junction and the Canada border to provide information, including active fault hazards, relevant to a proposed Alaska-Canada gas pipeline. During the 2006, 2007, and 2008 field seasons, geologic features indicative of possible youthful surface faulting in or near the western half of the corridor between Delta Junction and Dot Lake were identified by helicopter and fixed-wing air reconnaissance augmented by interpretation of stereo air photos, remotely sensed images, and aeromagnetic and electromagnetic (EM) data.

Field studies, including ground reconnaissance and mapping, topographic profiling, trenching, coring, and ${ }^{14} \mathrm{C}$ dating of surficial sediments on several of these lineaments, documented four faults with late Pleistocene and Holocene surface offsets. The largest of these faults is the previously unrecognized Dot "T" Johnson fault, a major west-trending, south-dipping thrust fault bordering the northern margin of the Alaska Range along the south side of the Tanana River valley. This fault is interpreted to be an eastern extension of the Northern Foothills Fold and Thrust Belt (NFFTB), a system of large, youthful, range-parallel anticlines, synclines, and thrust faults on the north flank of the Alaska Range west of the Delta River. Several trenches across the Dot "T" Johnson fault exposed faulted latest Pleistocene and Holocene sediments with evidence for multiple displacement events, each resulting in more than $4 \mathrm{~m}$ of dip-slip displacement on a $\sim 20^{\circ}$ dipping surface fault. The Dot "T" Johnson fault defines the modern structural boundary between the Alaska Range foothills and the Tanana Valley and Yukon-Tanana Upland.

Two of the faults identified as active in this study, the Canteen and Granite Mountain-Panoramic faults, are northeast-trending, left-lateral, strike-slip faults that connect segments of the Dot “T” Johnson thrust system, where they are separated by large left steps. The Granite Mountain and Panoramic faults, located at the base of the northwest flank of Granite Mountain, are about $17 \mathrm{~km}$ long and connect the east end of the Donnelly Dome fault, the easternmost previously recognized thrust fault in the NFFTB, with the northwest end of the Granite Mountain segment of the Dot "T" Johnson thrust. The Canteen fault is about $12 \mathrm{~km}$ long and joins the southeast end of the Granite Mountain segment with the west end of the Dot Lake segment of the Dot "T" Johnson fault. The Canteen fault horizontally offsets two Donnelly age ( $20 \mathrm{ka}$ ) lateral moraines about $32 \mathrm{~m}$, and a late Deltaage ( $\sim 0 \mathrm{ka}$ ) lateral moraine about $110 \mathrm{~m}$, indicating an average latest Pleistocene and Holocene horizontal rate of slip of about $1.6 \mathrm{~mm} / \mathrm{yr}$. Because the Canteen fault is interpreted to be a strike-slip tear in the hanging wall of the Dot "T" Johnson fault, the Canteen fault slip rate is a proxy for the shortening rate across the Dot "T" Johnson thrust.

The Billy Creek fault is a northeast-trending, left-lateral, strike-slip fault in the Yukon-Tanana Upland north of the Tanana River valley. A trench across the Billy Creek fault exposed a steeply dipping fault that vertically offsets layers of colluvium interbedded with loess and three fault-generated colluvial wedges. No datable material was recovered from the trench, but the faulted deposits are interpreted to be Holocene on the basis of weathering and soil development.
\end{abstract}

\section{INTRODUCTION}

The Alaska Highway is the principal land transportation route between interior Alaska, Canada, and the lower 48 United States and is the locus of significant planned and proposed development. In the Tanana River valley between Delta Junction and the Canada border the Alaska Highway corridor is a 25-km-wide, 320-km-long swath centered on the highway (fig. 1). It includes proposed routes for an Alaska-Canada natural gas pipeline and an extension of the Alaska Railroad through Canada (Solie and Burns, 2007). To allow informed evaluations of future development plans and guide engineering and design decisions regarding the proposed natural gas pipeline, the Alaska Railroad extension and other development in the corridor, the Alaska State Legislature in 2005 authorized a multi-year geologic framework

\footnotetext{
${ }^{1}$ Carver Geologic Inc., P.O. Box 52, Kodiak, Alaska 99615

${ }^{2}$ Alaska Division of Geological \& Geophysical Surveys, 3354 College Road, Fairbanks, Alaska 99709

${ }^{3}$ Department of Geological Sciences, 1272 University of Oregon, Eugene, Oregon 97403

${ }^{4}$ Department of Geologic Engineering, University of Alaska Fairbanks, Fairbanks, Alaska 99775
} 


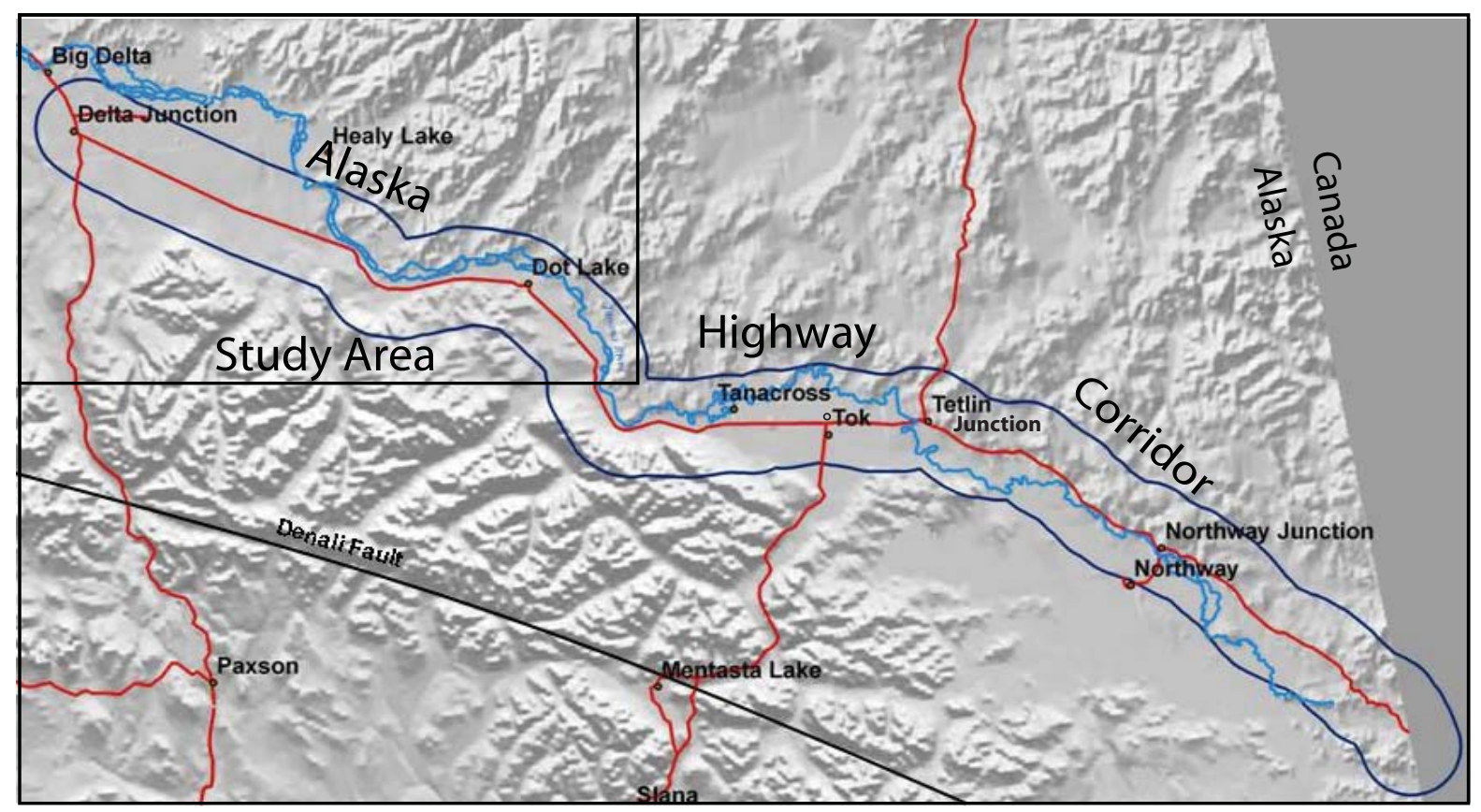

Figure 1. The Alaska Highway corridor is centered on the Alaska Highway between Delta Junction and the Canadian border. The field investigations for this study were conducted along the western part of the Alaska Highway corridor in the Tanana River valley and adjacent areas between Delta Junction and the village of Dot Lake.

assessment to be conducted by the Alaska Division of Geological \& Geophysical Surveys (DGGS). One of the components of the project includes mapping and characterization of active and potentially active faults in and near the Alaska Highway corridor. This report summarizes the fault studies of the framework project conducted in the western section of the corridor between Delta Junction and Dot Lake during the 2006, 2007, and early 2008 field seasons and presents the preliminary results and conclusions from these active fault investigations.

Active faults are defined as faults that show evidence of surface displacement during the Holocene (last $\sim 10,000 \mathrm{yr}$ ) and have the potential for movement in the future. The purpose of the investigations reported herein is to identify and document active and potentially active faults that could impact development of infrastructure in the Alaska Highway corridor. These results are intended to guide users to specific potential geohazards that will require additional study to more fully determine the location, slip rates, and movement history on individual faults. Due to the reconnaissance nature of this work, we cannot rule out the possibility that additional studies will identify active faults in or near the corridor that were not identified in this investigation. In this report, in order to distinguish active and potentially active faults from other linear geologic elements, we have reserved the term "fault" for those faults on which we observe evidence of Holocene movement. In this report, the term "lineament" includes linear features observed on air photos or remotely sensed imagery, or linear geomorphic features seen in the field that may be faults with no known evidence of movement during the last 10,000 years or features not related to faulting at all.

\section{SEISMOTECTONIC SETTING OF THE TANANA RIVER VALLEY REGION OF ALASKA}

The active tectonics of interior Alaska reflect the effects of 30-40 mm/yr of right-lateral relative plate motions at the northern end of the Queen Charlotte-Fairweather transform fault, 55-60 mm/yr of convergence of the Pacific and North American plates along the eastern part of the Aleutian subduction zone, and resulting complex deformation distributed across a wide region in southcentral and southwestern Alaska. The right-lateral Denali-Totschunda fault system, a major branch of the Fairweather fault, defines the broadly arcuate northern edge of the deforming Yakataga and Kenai crustal blocks (fig. 2). Motions of these crustal blocks along the arc of the Totschunda-Denali fault system result in a counterclockwise rotation of the deforming North American plate margin in southcentral and southwest Alaska. Slip rates along the central Denali fault, source of the 2002 M7.9 Denali Fault earthquake, are about 9-14 mm/yr (Matmon and others, 2006). 


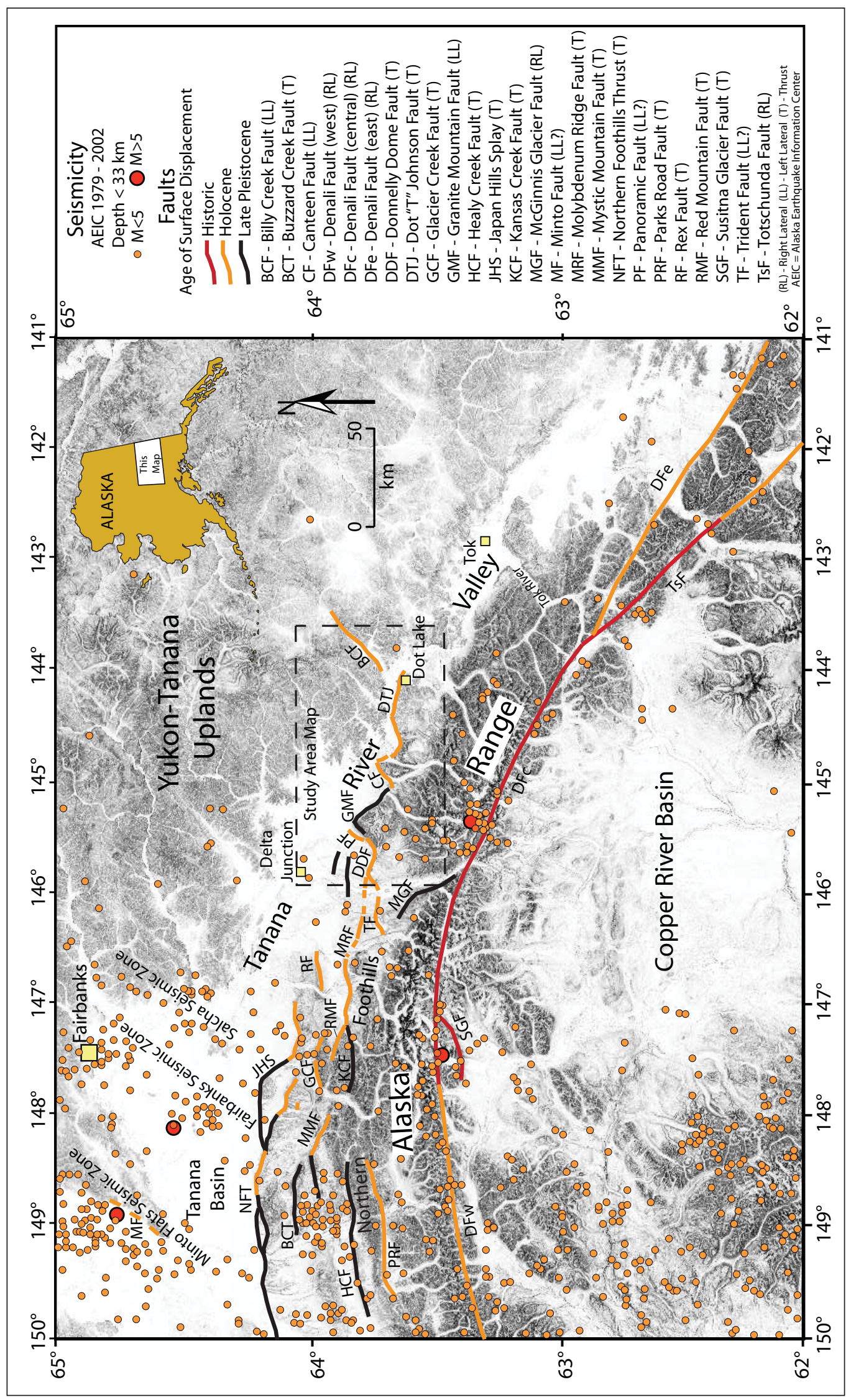

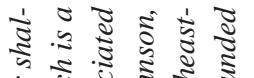

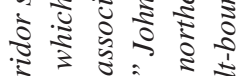
نे उ)

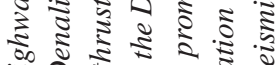
० 0 范

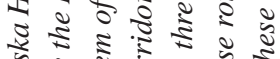

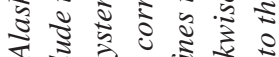
๘

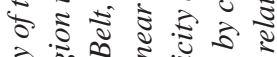

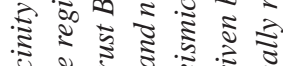

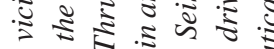

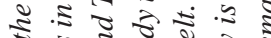
క气 ธี

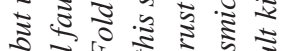
की ปั उे के व फ ร ธิ ปั ธิ㇒

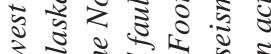
3 考 ริ

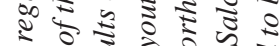

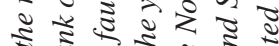
इ

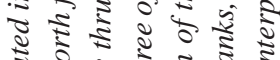

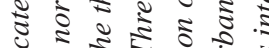
ㅇำ

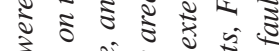
पे ڤึ ปี

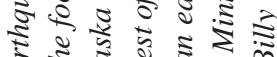

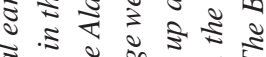
क्ष

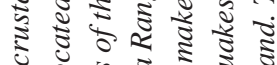

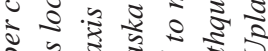

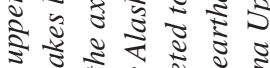

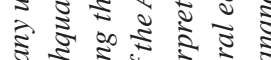

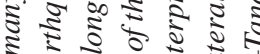
i क व 5.5 व

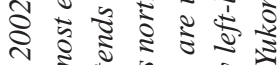

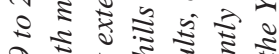
बू.

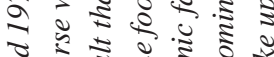
ऽ : ॠ ริ 3 के 2 क

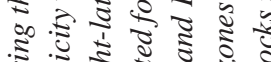

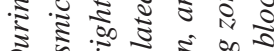
คิ ริ 疍 
Most of the plate motions are accommodated on highly seismic, active plate boundaries and on major crustal faults within the North American plate margin, including the Denali fault system. Active tectonics north of the central Alaska Range is evidenced by historic seismicity and geologic and geomorphic indications of youthful faulting, folding, uplift, and subsidence.

Several investigators have recently recognized the northern foothills region of the Alaska Range as a distinct neotectonic region, the Northern Foothills Fold-and-Thrust Belt (NFFTB) (Ridgway and others, 2002; Bemis, 2004). Active tectonics of the central Alaska Range south of the northern foothills is dominated by the right-lateral Denali fault that accommodates much of the westward component of motion between the Yakataga and Kenai blocks and interior Alaska. However, a component of north-directed motion driven by Yakataga and Kenai block convergence with interior Alaska is transferred across the Denali fault and accommodated by deformation of the north flank of the Alaska Range. West of the corridor study area, the NFFTB is $\sim 50 \mathrm{~km}$ wide and includes generally east-to-west-trending thrust faults and associated fault-generated folds that impart a pronounced east-west grain to the topography (fig. 2). North-flowing rivers heading in the Alaska Range are antecedent to the folds and faults and their long profiles show perturbations related to these structures (Bemis, 2004; Bemis and Wallace, 2007; Lesh and Ridgway, 2007). The folds and faults deform late Neogene and Quaternary alluvial surfaces and fluvial terraces. Shortening across the NFFTB in the vicinity of the Nenana River, based on a balanced cross-section analysis of deformed late Tertiary Usibelli Group and Nenana Gravel, is $~ 8.8 \mathrm{~km}$ (Bemis, 2004). Assuming the onset of thrust faulting and folding in the region coincided with the end of deposition of the Nenana Gravel $\sim 3$ Ma ago, the average shortening rate across the NFFTB in the vicinity of the Nenana River is $\sim 3 \mathrm{~mm} / \mathrm{yr}$. Seismicity in the northern foothills region supports this interpretation (Doser, 2004).

West of the corridor study area, the northern foothills of the Alaska Range are bordered on the north by the actively subsiding Tanana foreland basin that underlies extensive alluvial and swampy lowland in the Tanana River valley. The Tanana basin narrows and shallows to the east in the vicinity of the study area. The north side of the Tanana basin bounds the Yukon-Tanana Upland, a region of low hills and mountains dissected by mature drainages. Seismicity north of the northern foothills includes several northeast-trending zones of frequent earthquakes. In the Fairbanks region, these zones include the Minto Flats, Fairbanks, and Salcha seismic zones (fig. 2). Focal mechanisms for earthquakes in these seismic zones are dominantly left-lateral. East of Fairbanks, northeast-oriented streams parallel to the seismic belts indicate structural control of the drainage patterns by youthful faults. These structures are interpreted to reflect deformation from clockwise horizontal rotation of fault-bounded blocks between the Denali and Tintina fault systems (Page and others, 1995; Lesh and Ridgeway, 2007).

Upper crustal seismicity in the Tanana River valley region includes many earthquakes west of the study area and modest seismicity along the Denali fault south of the corridor, but few earthquakes have been located in the corridor (fig. 2). The seismicity shown on figure 2 is from the National Earthquake Information Service database for the period 1979 to 2002. In order to provide a view of the regional background seismicity we have not included the main shocks (M 6.7 and 7.9) or aftershocks from the 2002 Denali fault earthquake sequence. The seismicity in the Northern Foothills region west of the study area is similar to the seismicity in the northern flank of the Alaska Range adjacent to the corridor.

The 2002 Denali Fault earthquake sequence generated surface displacement on the previously unknown Susitna Glacier fault, the central section of the Denali fault, and the northern part of the Totschunda fault (Eberhart-Phillips and others, 2003). Surface displacement also occurred on part of the central section of the Denali fault in the vicinity of the Delta River in 1912 (Carver and others, 2004). No other historic surface faulting events are known in central Alaska.

Recent mapping in the northern foothills of the Alaska Range has identified a number of faults with late Pleistocene and Holocene displacement (fig. 2) (Bemis and others, 2005; Thoms, 2005; Carver and others, 2006). The majority of these are relatively low-slip-rate thrust faults interpreted to accommodate regional north- to south-directed contraction resulting from convergence of the Pacific plate and collision of the Yakataga block in southeast and southcentral Alaska with the North American plate north of the Denali fault.

In the study area we documented four faults with Holocene displacement (fig. 3): the Panoramic, Canteen, Dot "T" Johnson, and Billy Creek faults. The Dot " $\mathrm{T}$ ” Johnson fault is a generally east-to-west-trending, south-dipping, low-angle thrust fault that borders the northern flank of the Alaska Range along the southern margin of the Tanana River valley and is interpreted to be the eastern extension of the NFFTB. The Panoramic and Canteen faults are north-trending, left oblique-slip faults that join left-stepping segments of the Dot "T" Johnson thrust. The Billy Creek fault is a left-lateral strike-slip fault on the north side of the Tanana River valley. This fault has a northeast trend parallel to the Minto Flats, Fairbanks, and Salcha seismic zones. 


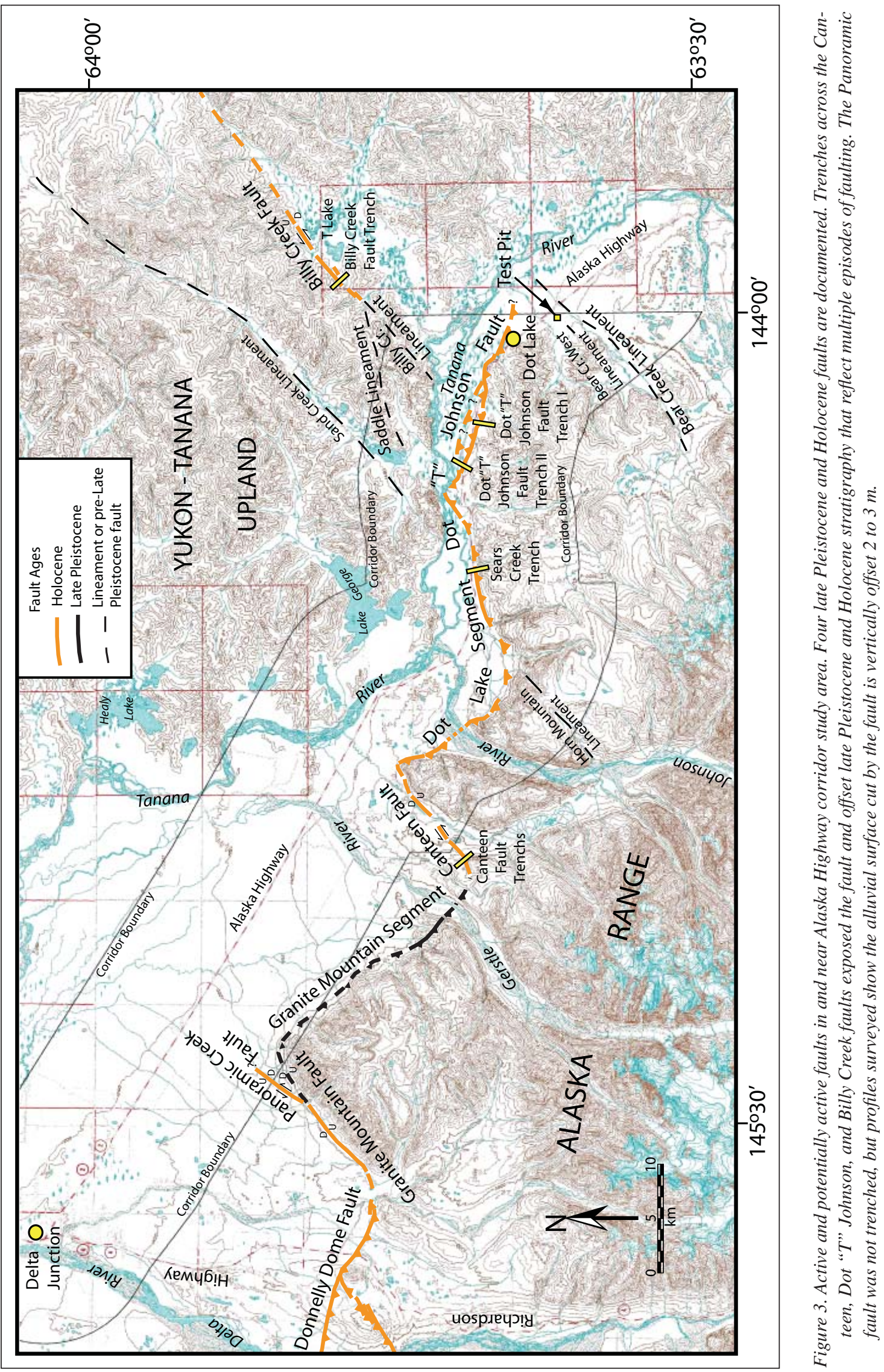




\section{FIELD AND ANALYTICAL METHODS}

The overall approach used for the study of active and potentially active faults in the corridor included an initial interpretation of stereo air photos, remotely sensed imagery, digital elevation models (DEMs), and topographic maps of the corridor and surrounding regions. We also conducted a review of published and unpublished reports and geologic and geophysical survey maps to identify and locate lineaments and potentially active faults for further study. This initial phase was followed by fixed-wing and helicopter reconnaissances of the corridor and adjacent regions with emphasis on potential faults and lineaments identified from the review of literature, air photos, remotely sensed imagery, and maps. Based on the initial studies and the air reconnaissances, we identified lineaments and potentially active faults judged to warrant further study in the field and selected sites for detailed investigation. The detailed investigations included geologic and geomorphic mapping, scarp profiling, measurement of scarp height and fault offset, and at selected sites, trenching and coring to develop paleoseismic information for active fault characterization.

Coordinates for all field locations were collected using a hand-held GPS unit (no differential correction was applied). Where lineaments with field characteristics indicative of active or potentially active faults were identified, the features were mapped by low-altitude helicopter overflights with GPS coordinates taken at closely spaced intervals along the lineaments. GPS locations were also taken where surface fieldwork, including topographic profiling and trenching, was done. Table 1 presents coordinates as latitude and longitude (based on the NAD 27 Alaska datum) and in UTM coordinates (based on the NAD 27 datum, UTM zone 6 or 7 projections) for trench sites and selected sites where field measurements were made.

Trench sites were chosen to transect features suspected to be active faults, in order to expose cross sections of faults and the most recent stratigraphy. At sites that were inaccessible to motorized excavation equipment, we hand-dug the trenches. To facilitate field interpretation and logging, we used nails to pin colored flagging along exposed contacts and faults on the cleaned trench walls. Logging of the trench walls was referenced to a grid of horizontal and vertical string lines on the exposed trench walls. Using this grid, each feature was accurately measured and transferred to gridded plastic film. Each stratigraphic layer and feature of interest was described and locations of radiocarbon samples were recorded. Soil and sediment colors for each stratigraphic unit were defined using a Munsell Soil Color chart. Where possible, we collected radiocarbon samples from layers bounding faulting

Table 1. Location of trenches, core sites and scarp profiles in the Alaska Highway Corridor, Mount Hayes and Tanacross Quadrangles, Alaska

\begin{tabular}{|c|c|c|c|c|c|c|}
\hline Site & $\begin{array}{r}\text { Latitude } \\
\text { (degrees) }\end{array}$ & $\begin{array}{l}\text { Longitude } \\
\text { (degrees) }\end{array}$ & $\begin{array}{l}\text { UTM E } \\
\text { NAD } 27\end{array}$ & $\begin{array}{r}\text { UTM N } \\
\text { NAD } 27\end{array}$ & $\begin{array}{l}\text { UTM } \\
\text { Zone }\end{array}$ & $\begin{array}{c}\text { USGS } \\
\text { 1:63,360 } \\
\text { quadrangle }\end{array}$ \\
\hline Billy Creek fault trench & 63.7951 & -143.9333 & 355511 & 7077309 & 7 & Tanacross D-6 \\
\hline Billy Creek fault profile 1 & 63.7951 & -143.9333 & 355511 & 7077309 & 7 & Tanacross D-6 \\
\hline Billy Creek fault profile 2 & 63.7924 & -143.9295 & 355687 & 7077196 & 7 & Tanacross D-6 \\
\hline Billy Creek fault profile 3 & 63.7945 & -143.9292 & 355711 & 7077432 & 7 & Tanacross D-6 \\
\hline Billy Creek fault profile 4 & 63.7934 & -143.9254 & 355892 & 7077303 & 7 & Tanacross D-6 \\
\hline Canteen fault core site & 63.6067 & -145.0118 & 598290 & 7064544 & 6 & Mount Hayes C-3 \\
\hline Canteen fault trench & 63.6967 & -145.0114 & 598311 & 7064554 & 6 & Mount Hayes C-3 \\
\hline $\begin{array}{l}\text { Dot “T” Johnson fault } \\
\text { trench I }\end{array}$ & 63.6824 & -144.1991 & 638523 & 7064465 & 6 & Mount Hayes C-1 \\
\hline $\begin{array}{l}\text { Dot “T” Johnson fault } \\
\text { trench II }\end{array}$ & 63.6926 & -144.2791 & 634519 & 7065429 & 6 & Mount Hayes C-1 \\
\hline $\begin{array}{l}\text { Dot “T” Johnson fault } \\
\text { Sears Creek trench }\end{array}$ & 63.6810 & -144.2052 & 638220 & 7064502 & 6 & Mount Hayes C-2 \\
\hline Bear Creek west & 636194 & -143 9947 & 351570 & 7057887 & 7 & Mount Haves C-1 \\
\hline $\begin{array}{l}\text { Panoramic fault profile A } \\
\text { (east end) }\end{array}$ & 63.8391 & -145.4560 & 575951 & 7079803 & 6 & Mount Hayes D-3 \\
\hline $\begin{array}{l}\text { Panoramic fault profile B } \\
\text { (west end) }\end{array}$ & 63.8421 & -145.4534 & 576074 & 7080146 & 6 & Mount Hayes D-3 \\
\hline
\end{tabular}


events to bracket the age of paleo-earthquakes interpreted from the stratigraphy. Upon completion, we backfilled the trenches, re-contoured the trench sites, and replaced the natural vegetation.

The radiocarbon samples were carefully extracted to minimize contamination. Samples were stored in the field in aluminum foil bundles that were placed in labeled plastic bags after air-drying, and the dry samples were transferred to labeled glass vials once they were out of the field. Before being sent to the laboratory for analyses, each sample was inspected through a binocular microscope, picked clean of mineral debris, and for some samples, individual plant macrofossils or charcoal grains were separated for analysis. Beta Analytic Radiocarbon Dating Laboratory in Miami, Florida, performed the radiocarbon age analyses on the ${ }^{14} \mathrm{C}$ samples. All analysis was done using AMS methods and included ${ }^{13} \mathrm{C}$ corrections. Laboratory ages were calibrated using the OxCal v4.0 calibration program and the IntCal 04 calibration curve (Bronk Ramsey, 1995; 2001; Reimer and others, 2004). All ages are reported as calibrated 2 sigma ranges before present (cal yBP). The data in Appendix 1 report the method used, material type, paleoseismic significance, sample and laboratory numbers, laboratory age, ${ }^{13} \mathrm{C} /{ }^{12} \mathrm{C}$ ratios, and 2-sigma calendar calibration result for each of the 20 radiocarbon samples.

At the Canteen trench site we used a 1-in. diameter gouge corer to obtain 1- to 1.5-m-deep core samples with intact stratigraphy from a freshwater marsh and the margin of a shallow lake overlying the fault. We measured, described, and photographed the stratigraphy recovered in each core. The Munsell color of each stratigraphic layer was described. ${ }^{14} \mathrm{C}$ samples were collected from selected stratigraphic horizons and cores.

Scarp profiles and slope profiles across lineaments were measured using a hand level stabilized on an instrument rod of known height and vertical distances between survey points (fore-sights and back-sights) read from horizontal sightings on a stadia-surveying rod. Slope distances were measured with a 50-m tape. Horizontal distances, slope, and scarp profiles are plotted from the hand-level surveys.

\section{STRATIGRAPHY}

The Tanana River valley and adjacent Alaska Range foothills and Yukon-Tanana Upland along the Alaska Highway corridor are underlain by rocks of the Yukon-Tanana terrane composed of highly metamorphosed Precambrian to middle Paleozoic crystalline rocks, principally orthogneiss, schist, quartzite and semischist, and Cretaceous plutonic rocks. Locally a sequence of weakly consolidated middle and late Tertiary non-marine sedimentary rocks unconformably overlies the crystalline basement. We correlate these sedimentary rocks with the Usibelli Group and Nenana Gravels as described to the west (Wahrhaftig and others, 1969). The Oligocene and Miocene Usibelli Group makes up the lower part of the sedimentary section and the Pliocene Nenana Gravel overlies the Usibelli Group. The Usibelli Group includes silty and sandy lacustrine and swamp deposits and quartz-pebble-rich fluvial gravels containing extensive coal beds. Provenance and paleocurrent studies of the Usibelli Group sediments indicate they were deposited by south- and southwest-flowing, low-gradient streams into regionally extensive swamps from northern sources prior to initiation of uplift of the Alaska Range. The age of initial deposition of the Nenana Gravel and maximum limiting age for the initiation of uplift of the central Alaska Range is based on an ${ }^{40} \mathrm{Ar} /{ }^{39} \mathrm{Ar}$ age of $6.7 \pm 0.1 \mathrm{Ma}$ (Triplehorn and others, 1999) from an ash in the upper part of the Grubstake Formation, a lacustrine sequence that makes up the youngest unit of the Usibelli Group. In the corridor field area, rocks correlative with Usibelli Group were found in a down-faulted block on the Macomb Plateau southeast of Horn Mountain and along the northeast flank of the Granite Mountain massif.

In the type locality, Usibelli Group sediments are conformably overlain by the Nenana Gravel, which is composed of cobble and boulder conglomerates. The gravel includes a mix of granitic, metamorphic, and sedimentary lithologies. Provenance for the Nenana Gravel includes the Alaska Range and indicates a south-to-north transport direction for the gravels. The change from deposition of the Usibelli Group to the Nenana Gravel reflects initial uplift of the Alaska Range. Large-scale bedding in the gravels is conformable and channeling is minor, indicating deposition in a slowly subsiding basin. Gradual up-section coarsening of the gravels is interpreted to reflect increasing elevation of the adjacent Alaska Range (Wahrhaftig, 1958). In the corridor field area, the Nenana Gravel is exposed on the northeast flank of the Granite Mountain massif (Carter, 1980) where beds dip $60^{\circ}$ to $70^{\circ}$ to the north in the limb of a large anticline, on the Macomb Plateau capping the Usibelli Group sediments southeast of Horn Mountain, and as a thin veneer on the crest of Independent Ridge (Holmes, 1965; Holmes and Foster, 1968).

In many places, the northern foothills of the Alaska Range are capped by a widespread relict geomorphic surface. We interpret this surface to be the remnant of an exhumed low-relief middle Tertiary erosional landscape underlying the Usibelli Group and locally the Nenana Gravel (fig. 4). This exhumed surface predates the uplift of the Alaska Range and development of the northern foothills fold-and-thrust structures. 


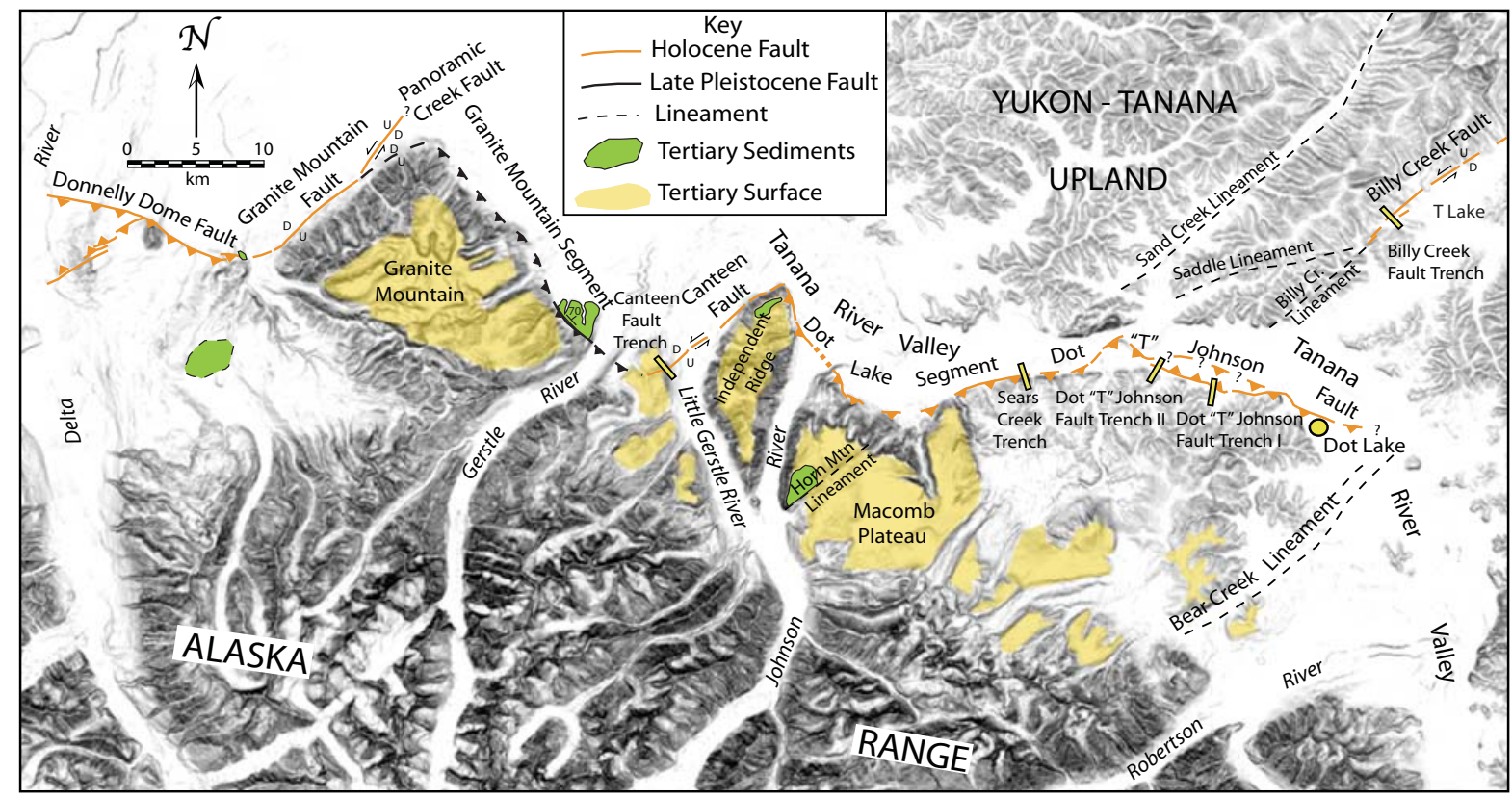

Figure 4. Middle and late Tertiary sediments of the Usibelli Group and Nenana Gravel and exhumed middle Tertiary surfaces in the study area serve as distinctive markers in interpreting post-Tertiary deformation in the study area.

A minimum age estimate for the termination of deposition of the Nenana Gravel comes from a K/Ar age of 2.8 Ma for the Jumbo Dome intrusion, a dacite plug that intrudes the gravels and deforms the post-Nenana Gravel surface (Wahrhaftig and others, 1969; Albanese, 1980).

The Neogene sediments and underlying low-relief erosion surface provide useful data for identifying and characterizing the major post-Tertiary structures that make up the fold-and-thrust belt on the north side of the Alaska Range. The parallel bedding and low-energy depositional environments recorded by the Usibelli Group reflect tectonic quiescence and limit the onset of fold-and-thrust belt tectonics to the latest Tertiary or early Quaternary. Where these well-bedded sediments are cut by faults, bedding is commonly steeply dipping and disrupted. Between major faults, Tertiary sediments are flat lying or exhibit gentle north or south dips associated with large east- to west-oriented fault-generated folds.

\section{QUATERNARY STRATIGRAPHY}

The Quaternary sediments in the study area are composed predominantly of alluvium, coarse fluvial and glaciofluvial gravels, and loess. Along upper reaches of the major drainages in the foothills of the Alaska Range, various forms of glacial drift, including ablation till, ice-contact stratified drift, outwash, and glaciolacustrine sediments, make up the Quaternary deposits. Post-glacial (Holocene) sediments include colluvium, alluvium, fluvial gravels, and loess. The Quaternary sediments have traditionally been mapped as Quaternary glacial and interglacial climate-stratigraphic units. Several different stratigraphic schemes have been proposed for the region, and the ages of some glacial units remain controversial (Péwé and Reger, 1983). Surficial geologic mapping as part of the Alaska Highway corridor study more fully describes the stratigraphy and glacial history of the study area (Reger and others, 2008b).

\section{EARLY AND MIDDLE QUATERNARY STRATIGRAPHY}

Early-middle Quaternary sediments along the northern flank of the Alaska Range and adjacent Tanana River valley are dominated by high-energy fluvial, glaciofluvial and alluvial cobble-boulder gravels and deeply weathered ablation till. In the western NFFTB these sediments include the Teklanika, Bear Creek, and Brown drifts assigned to three early or middle Pleistocene glaciations (Thorson, 1986). Equivalent glacial sediments have not been identified in the corridor study area. 


\section{LATE QUATERNARY STRATIGRAPHY Delta Glaciation}

During at least three late Quaternary glacial intervals, glaciers in the central Alaska Range thickened and expanded and on the south side of the range coalesced with the Cordilleran Ice Sheet. On the north flank of the Alaska Range, large valley glaciers advanced down the principal river and stream valleys into the northern foothills and Tanana River valley. These glaciers left bulky end moraines and extensive outwash terraces. In the Nenana River valley west of the corridor study area, the late Quaternary glacial stratigraphy, from oldest to most recent, includes the Lignite Creek drift (Marine Isotope Stage [MIS] 6, 160 ka), Healy drift (MIS 4, 65-70 ka), and Riley Creek till (MIS 2, 17-25 ka) (Begét, 2001; Begét and Keskinen, 1991).

Two major late Quaternary glacial advances (the Delta and Donnelly glaciations) are recognized in the corridor study area. Nested, successively younger complexes of end and recessional moraines represent at least two extensive advances of large piedmont ice lobes down the Delta River into the western end of the corridor and large valley glaciers down other major drainages from the Alaska Range into the corridor (Reger and Péwé, 2002). The earlier and most extensive of these moraines were deposited during the Delta glaciation. The Delta moraines form a several-kilometer-wide belt of rounded hills and ridges that extends down the flanks of the Delta River valley to near the junction of the Delta and Tanana rivers. The moraines are composed of well-rounded cobbles and boulders in a sandy matrix. A weathering profile up to $5 \mathrm{~m}$ thick marked by yellow-brown oxidization colors has developed into the Delta moraine surfaces. Erratics are scarce, and surface boulders are weathered and pitted. Partially or completely filled kettle ponds and small lakes are present on the Delta moraines.

The age and Marine Isotope Stage correlation of the Delta glaciation are uncertain. Several early researchers assigned the Delta glaciation to the early Wisconsinan (MIS 4, 65-70 ka) (Holmes, 1965; Péwé and others, 1953). Reger and Péwé (2002) summarized previous work concerning the age of the Delta Glaciation. They reported the Sheep Creek tephra $(190 \pm 20 \mathrm{ka})$ is stratigraphically above the Delta drift and assign the Delta glaciation to MIS 6. Begét and Keskinen (2003) found and reported the Old Crow tephra (140 \pm 10 ka) overlying alluvium that they correlated with the Delta glaciation and assigned the Delta glaciation to MIS 6. Subsequently, Westgate and others (2008) revised the ages of Sheep Creek tephras in the Yukon Territory and also assigned the Delta glaciations to MIS 6. Cosmogenic-exposure ages have recently identified MIS 4 moraines in the Yukon (Lacelle and others, 2007; Ward and others, 2007) that are correlated with the Delta glaciation. Cosmogenic-exposure dating of Delta moraines in eastcentral Alaska has also yielded MIS 4 ages (Briner and others, 2005; Young and others, 2007). A more complete recent review of the age assignments for the Delta glacial deposits in the corridor region can be found in Reger and others (2008b). It is likely that at different places along the northern flank of the Alaska Range several ages of moraines have been mapped as Delta deposits.

\section{Donnelly Glaciation}

The Donnelly drift represents the late Pleistocene glacial deposits on the north flank of the Alaska Range. The Donnelly drift includes till and ice-contact stratified drift deposited as sharp-crested terminal, lateral, and recessional moraines and well-sorted glaciofluvial sands and gravels that form outwash valley trains and terraces. Weathering profiles in the Donnelly deposits are markedly less developed than in the older Delta drift, and consist of about a meter of oxidization. Erratics are common and many unfilled ponds and small lakes are present in the Donnelly moraines. The Donnelly moraine complex in the Delta River valley includes two prominent nested end moraines that have been interpreted to reflect two stades associated with two late Pleistocene advances during the Donnelly glaciation (Péwé and Holmes, 1964; Reger and Péwé, 2002). The Donnelly glaciation is correlated to MIS 2 (17-25 ka). Regionally this glaciation reached its maximum extent about 20 ka.

\section{Late Quaternary Glaciofluvial and Alluvial Sediments}

A regionally extensive, gently north-sloping alluvial plain of coalescing alluvial and outwash fans and terraces extends into the Tanana River valley from the margin of the northern foothills. This alluvial and outwash surface grades to the floodplain of the west-flowing Tanana River. In the Tanana River valley, nested fluvial terraces are preserved along the south side of the valley, but are largely lacking on the north side where the river is actively eroding the south margin of the Yukon-Tanana Upland. Some of these terraces contain scattered large boulders up to several meters in diameter. These terraces are interpreted to be flood terraces generated by outburst floods from collapsed ice dams across the Tanana River valley by Delta and Donnelly age Robertson River glaciers (Reger and others, 2008a, b) and from Glacial Lake Atna, which occupied part of the Copper River Basin and drained into the Tanana River through Mentasta Pass and the Tok River valley (Schmoll, 1984). 
The youngest widespread sediment in the Delta-Tanana River region is wind-blown, very fine sand and silt that form a 1- to 3-m-thick loess blanket mantling much of the landscape. This loess was derived from the floodplains of meltwater rivers and streams draining the glaciated Alaska range. ${ }^{14} \mathrm{C}$ age analyses from many locations in the Delta-Tanana River region show that deposition of the loess has been ongoing through the Holocene (Muhs and others, 2003).

\section{ACTIVE AND POTENTIALLY ACTIVE FAULTS}

\section{BILLY CREEK FAULT}

The Billy Creek fault is shown on the Neotectonic Map of Alaska as a northeast-trending lineament with "possible Neogene displacement" (Plafker and others, 1994). We mapped the Billy Creek fault from about $7 \mathrm{~km}$ north of the Tanana River northeast for at least $35 \mathrm{~km}$ along the linear Billy Creek valley and beyond to the northeast (fig. 3). We were not able to trace the fault south into the Tanana River valley because dense forest obscured the ground from the air and prevented helicopter landings and surface reconnaissance. Two possible south extensions of the fault into the Tanana River valley were identified from air photos and on the basis of large-scale geomorphology: (1) a southwest linear trend of saddles and small stream valleys on strike with the mapped fault, labeled the Billy Creek lineament in fig. 2, and (2) a west-southwest alignment of ridge crest saddles and apparent left-lateral offset streams that extends from the southernmost point on the mapped trace of the fault to the vicinity of the south end of Sand Lake. Figure 3 shows this possible extension as the Saddle lineament. The Billy Creek fault is defined in the field by discontinuous aligned linear scarps, prominent vegetation lines, and linear streams along most of its length. In the lower part of the Billy Creek valley southwest of "T" Lake, the crests of southeast-trending spur ridges exhibit left-lateral offset on youthful-appearing scarps up to $3 \mathrm{~m}$ high (fig. 5). These scarps are east facing on south slopes and west facing on north slopes of the spur ridges (fig. 6).

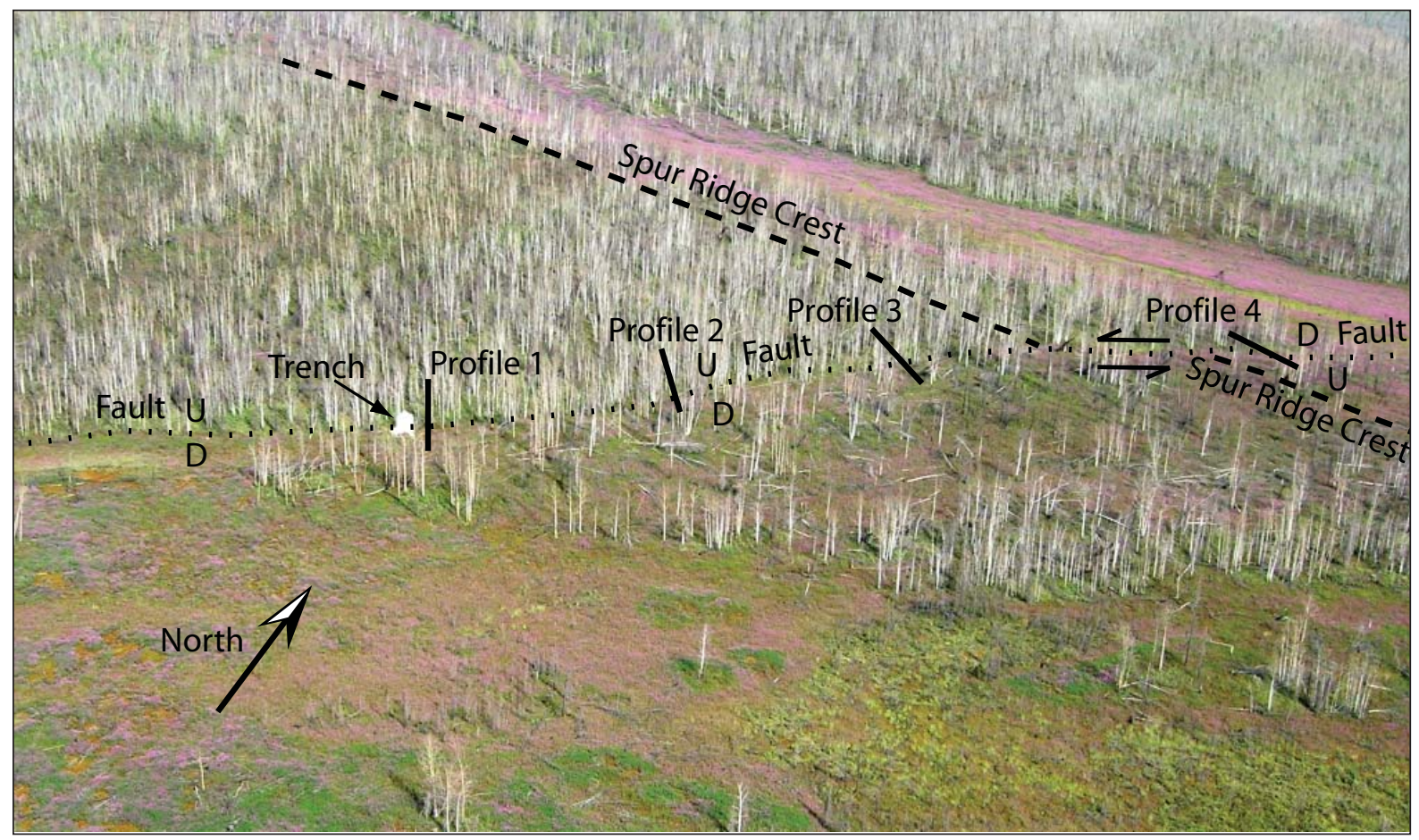

Figure 5. Oblique aerial photograph of the Billy Creek fault at the trench site. The northeast- trending fault forms a prominent scarp about 2 to $3 \mathrm{~m}$ high marked by a vegetation contrast between trees to the northwest and tundra to the southeast, probably reflecting differences in depth to shallow groundwater across the fault. The trench (covered by a white weather shelter) is in the middle left half of the photograph. The locations of scarp profiles shown in figure 6 are shown on the photo. This area burned in a wildfire in 2004. The photograph was taken in 2007. $U=$ upthrown side of fault; $D=$ downthrown side of fault. 
Figure 6. Scarp profiles on the Billy Creek fault at the trench site. Profiles 1, 2, and 3 are on the southwest side of a broad, rounded, northwest-trending spur ridge and have southeast-facing scarps. Profile 4 on the northeast flank of the ridge has a northwest-facing scarp. Scarp aspects reflect left-lateral offset of the ridge.

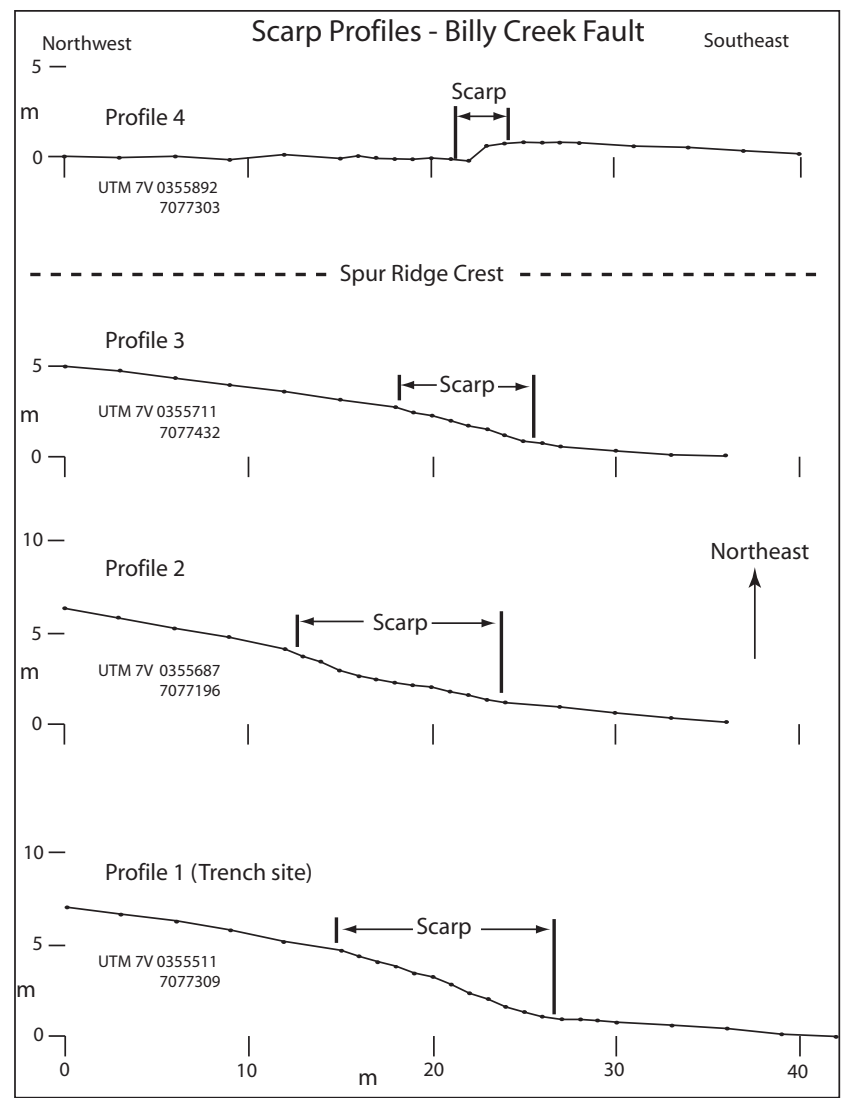

\section{BILLY CREEK FAULT TRENCH}

In 2007, we investigated the Billy Creek fault, looking for evidence of late Pleistocene or Holocene displacements. A trench was excavated at the base of an approximately 2.5-m-high, southeast-facing, northeast-trending scarp on the northwest side of the Billy Creek valley about 2 km west of “T” Lake (fig. 3). The trench was approximately $5 \mathrm{~m}$ long and about 1.2 to $2 \mathrm{~m}$ deep (fig. 7). Jointed and fractured granitic bedrock was exposed in the northwestern end of the trench underlying the scarp face. To the southeast, downslope from the bedrock, three colluvial wedges composed of nonsorted angular granitic cobbles in a pebbly sandy matrix and intervening layers of poorly sorted and locally laminated sandy slopewash colluvium were exposed in the trench. A thin layer of loess and a weakly developed cambic soil with a 25- to 30-cm A-B horizon caps the sediments. The colluvial wedges and slopewash colluvium are in fault contact with the bedrock on two steeply northwest-dipping faults, one that terminates upward at the upper colluvial wedge and the other that terminates at the base of the upper slopewash colluvium. A small, secondary, northwest-dipping fault with about $10 \mathrm{~cm}$ of normal vertical separation on a well-bedded sandy layer cuts the trench about $2 \mathrm{~m}$ outboard of the base of the scarp. The colluvial wedges and interbedded slopewash sand layers are inclined downward toward the main faults between the secondary fault and the primary faults at the scarp base, with lower wedges more steeply inclined.

No datable material was recovered from the trench. Weak A-C soil profiles a few tens of centimeters thick were found at the surface and beneath the upper colluvial wedge. No evidence of cryoturbation or penetrative frost reworking of the deposits was exposed in the trench. The lack of periglacial reworking of the sediments in the trench, the weakly developed soils, and the steep scarp on the fault indicate the faulting is postglacial and is probably at least in part Holocene.

\section{CANTEEN FAULT}

The Canteen fault is a northeast-trending, left-oblique-slip fault that connects the eastern end of the monocline and thrust faults on the northeast flank of Granite Mountain with the west end of the Dot Lake segment of the Dot “T” Johnson fault, where the range front steps to the left along the Little Gerstle River (fig. 3). The Canteen fault was recognized during early investigations in the map area and was included on the Neotectonic Map of Alaska (Plafker and others, 1994) and documented by Bemis and others, (2005). Near its southwest end, the Canteen 


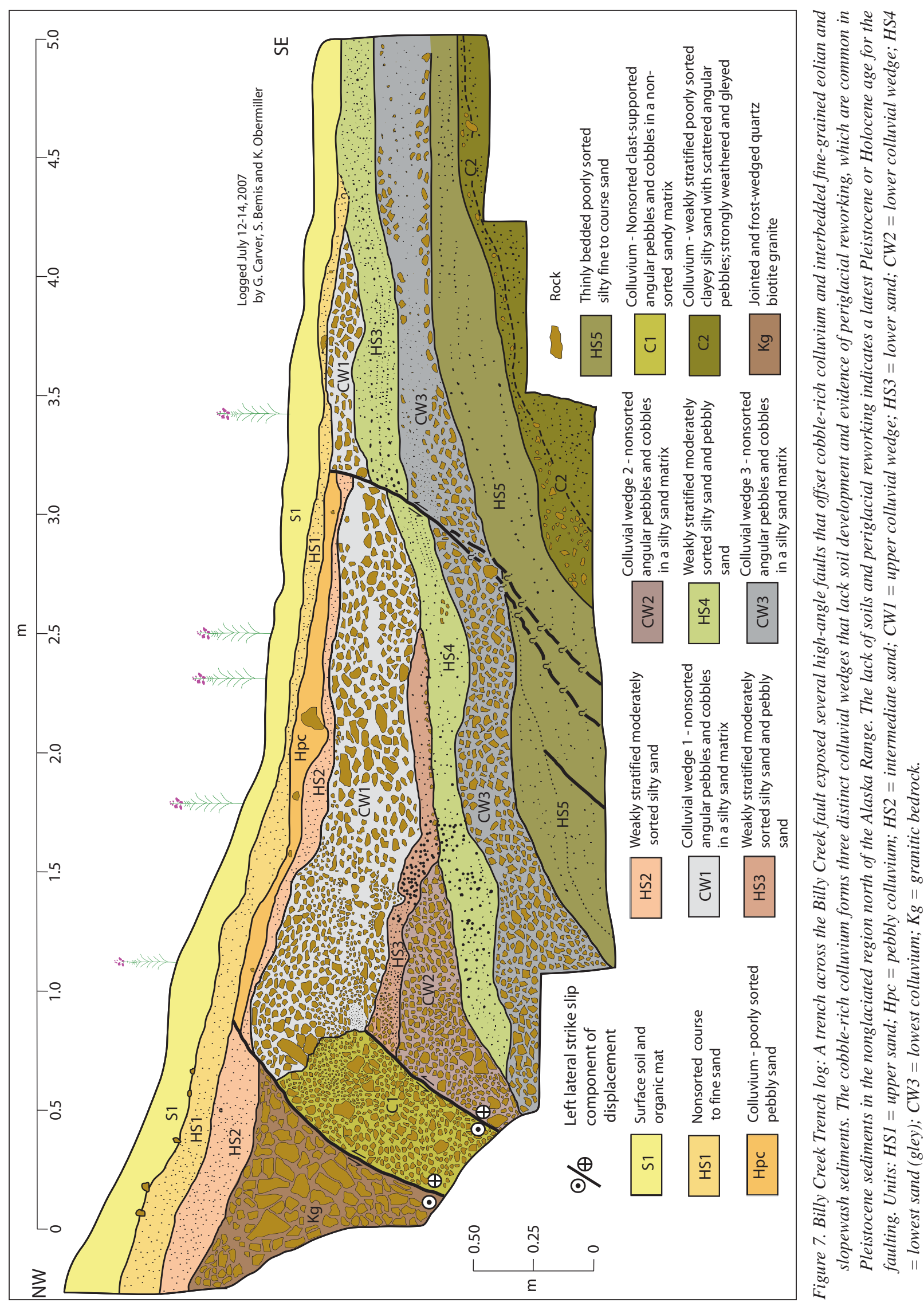


fault offsets two well-defined, sharp-crested lateral moraines of Donnelly age (Bemis and others, 2005), one large Delta-age lateral moraine, and the west wall of the Little Gerstle River valley (fig. 8). Left-lateral offset of Donnelly moraines is $32 \mathrm{~m}$. The age of the moraines, formed during the maximum extent of the Donnelly glaciation, is about $20 \mathrm{ka}$, indicating a late Pleistocene-Holocene slip rate for the fault of $1.6 \mathrm{~mm} / \mathrm{yr}$. The slip rate over the longer interval represented by the offset Delta moraine is less well constrained because the amount of offset of the Delta moraine is not well defined in the field; the moraine is generally absent in the Little Gerstle River valley on the south side of the fault. Assuming the Delta moraine south of the fault is located at the same place as the later Donnelly moraines, horizontal separation across the Canteen fault is about $230 \mathrm{~m}$, which we consider a maximum estimate. The minimum horizontal separation of the Delta moraine, measured from the valley wall margin south of the fault is about $110 \mathrm{~m}$ (fig. 8). Additionally, the age of the Delta moraine is not well constrained. Previous estimates assigned the Delta glaciation to MIS 4 ( 65-70 ka), MIS 6 ( 160-180 ka) and even MIS 8 ( 240 ka). Recent cosmogenic exposure dating by Young and others (2007) of Delta moraines in the Delta River valley west of the study area and Fish Lake valley east of the Canteen fault indicate an MIS 4 age of 65-70 ka. Assuming the MIS 4 age for the Delta Glaciation and the $230 \mathrm{~m}$ offset for the moraine, the fault slip rate would be about 3.5 $\mathrm{mm} / \mathrm{yr}$, far greater than the rate derived from the offset Donnelly moraines. The MIS 6 age and $230 \mathrm{~m}$ offset yields a rate of $1.3 \mathrm{~mm} / \mathrm{yr}$, somewhat less than the rate estimated from the Donnelly moraine offsets. The $65 \mathrm{ka}$ age (Young and others, 2007) and $110 \mathrm{~m}$ offset results in a slip rate of $1.7 \mathrm{~mm} / \mathrm{yr}$, very similar to the rate from the Donnelly moraines. We favor this latter interpretation because it is consistent with rates derived from Donnelly offsets.

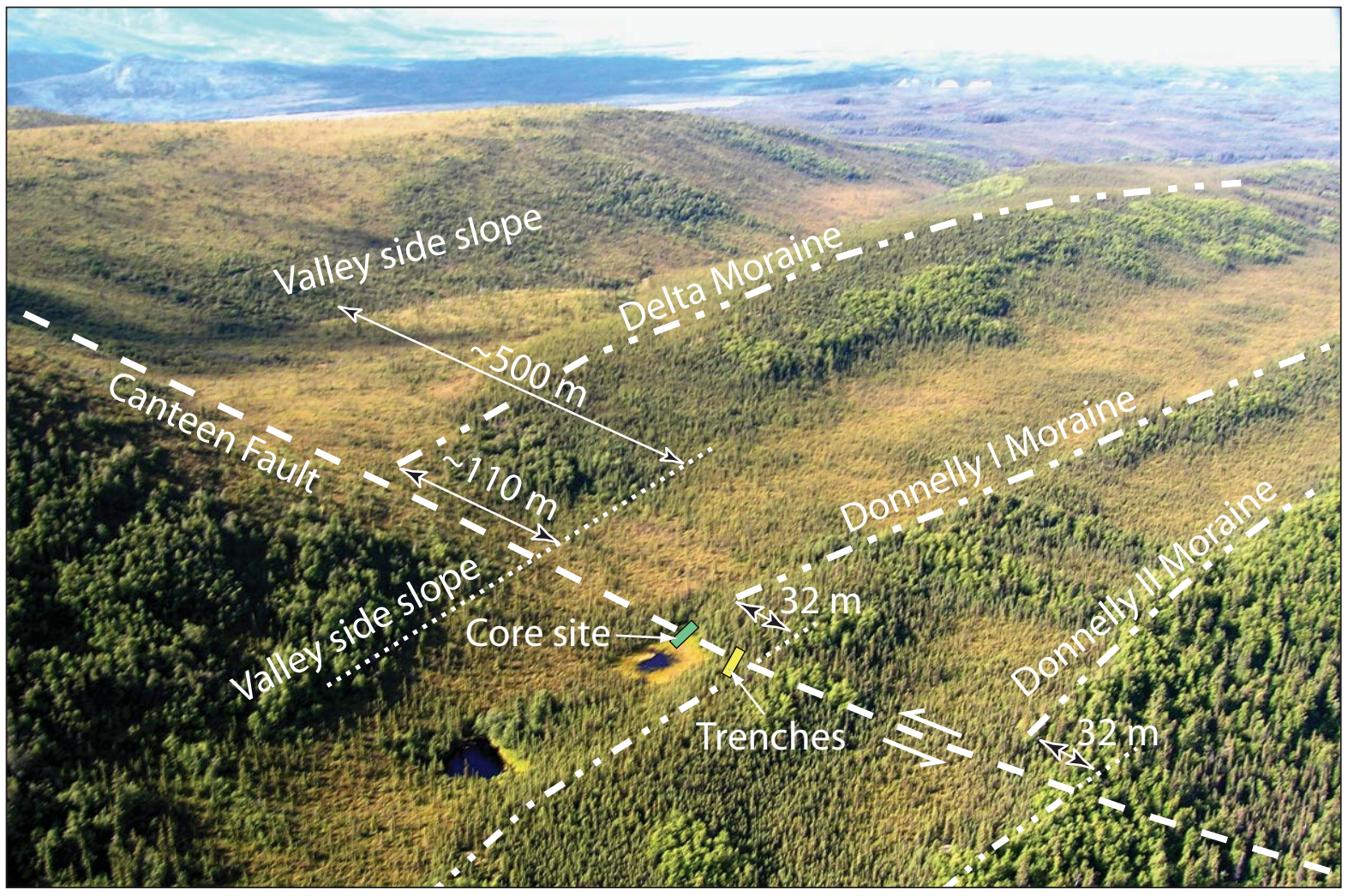

Figure 8. Oblique air photograph looking to the northwest of Donnelly- and Delta-age moraines offset by the Canteen fault on the west side of the Little Gerstle River valley. The pond core site (green box) and trench (yellow box) are shown. Left-lateral offsets of the Donnelly moraines $(32 \mathrm{~m})$ were measured with a surveying tape in the field. Offset of the Delta moraine $(\sim 110 \mathrm{~m}$ ) was determined from a GPS survey. The offset of the side slope of the river valley ( 500 m) was estimated from a vertical air photo. 


\section{CANTEEN FAULT CORES AND TRENCHES}

Field investigations in 2007 focused on the area of offset Donnelly-age lateral moraines on the west side of the Little Gerstle River valley. The left-lateral offset of the outer Donnelly moraine produced a "shutter ridge" that impounds the local drainage, producing a pond and marsh over the fault zone (fig. 9). Eleven hand-driven gouge cores were taken from the soft pond sediments straddling the fault, where the moraine is offset (fig. 9). The cores were taken along three parallel transects at $1 \mathrm{~m}$ intervals across the projection of the fault. The stratigraphy in the cores was logged (fig. 10) and 14 samples were collected for ${ }^{14} \mathrm{C}$ dating, of which six were submitted and dated (Appendix 1). Analysis of sediments from the array of marsh cores shows at least two fault strands with multiple displacement episodes. ${ }^{14} \mathrm{C}$ ages from the cores place age constraints for the multiple events to less than about 8 ka with the most recent event(s) less than 1 to 4 ka (fig. 10).

Four trench excavations were attempted at this site. Trench 1, about $3.5 \mathrm{~m}$ long, was excavated to a depth of about $1 \mathrm{~m}$ in frozen ground. A cobble and boulder diamicton of reworked till that lacked useful stratigraphy was exposed. Because of the lack of suitable stratigraphy or evidence of faulting, trench 1 was abandoned and backfilled. Trench 3, about $4 \mathrm{~m}$ long and $1.5 \mathrm{~m}$ deep, was dug into highly cryoturbated nonbedded frozen silt and very fine sand. This trench was cleaned and examined carefully for evidence of faulting. No faults were found, and, after examination, this trench was backfilled. Trench 4 encountered excessive groundwater at a depth of about 0.5 meter and flooded, so this trench was abandoned and backfilled.

Trench 2, located about $20 \mathrm{~m}$ east of the marsh, exposed the main trace of the fault and three subsidiary fault strands that offset interbedded colluvium and loess (fig. 11). The trench, about $2.5 \mathrm{~m}$ long and $1 \mathrm{~m}$ deep, was excavated in frozen ground and exposed boulder and cobble colluvium interbedded with layers of loess cut by four nearly vertical faults. One of these faults, labeled fault 1 in figure 11, separates distinctly different layers of colluvium containing predominantly rounded and subrounded till stones of mixed lithology south of the fault, and slope-derived colluvium containing sharply angular slabs of schist on the north side. In trench 2, at least three faulting events are documented by: (1) the lateral termination of loess L2 and colluvium C2 by fault 1 (earliest displacement event), (2) the upward termination of fault 4 by colluvium C1 (intermediate event), and (3) the upward termination of faults 1, 2, and 3 at the base of the surface peat layer P1 (most recent event) (fig. 11).

Seven ${ }^{14} \mathrm{C}$ samples were collected and dated from trench 2. Of these samples, sample CF-T2-14-12 from the lower part of the surface organic layer dated modern. A tephra in the surface peat, interpreted to be the northern lobe of the White River Ash, dated about 1,900 yBP (Lerbekmo and others, 1975), constrains the minimum age of the most recent displacement event. Two-sigma ${ }^{14} \mathrm{C}$ ages of 4,800-4,660 and 3,200-2,950 cal yBP (earliest displacement event), 2,960-2,780 cal yBP (penultimate event) and 2,300-1,180 cal yBP (most recent event) provide maximum age limits for faulting events.

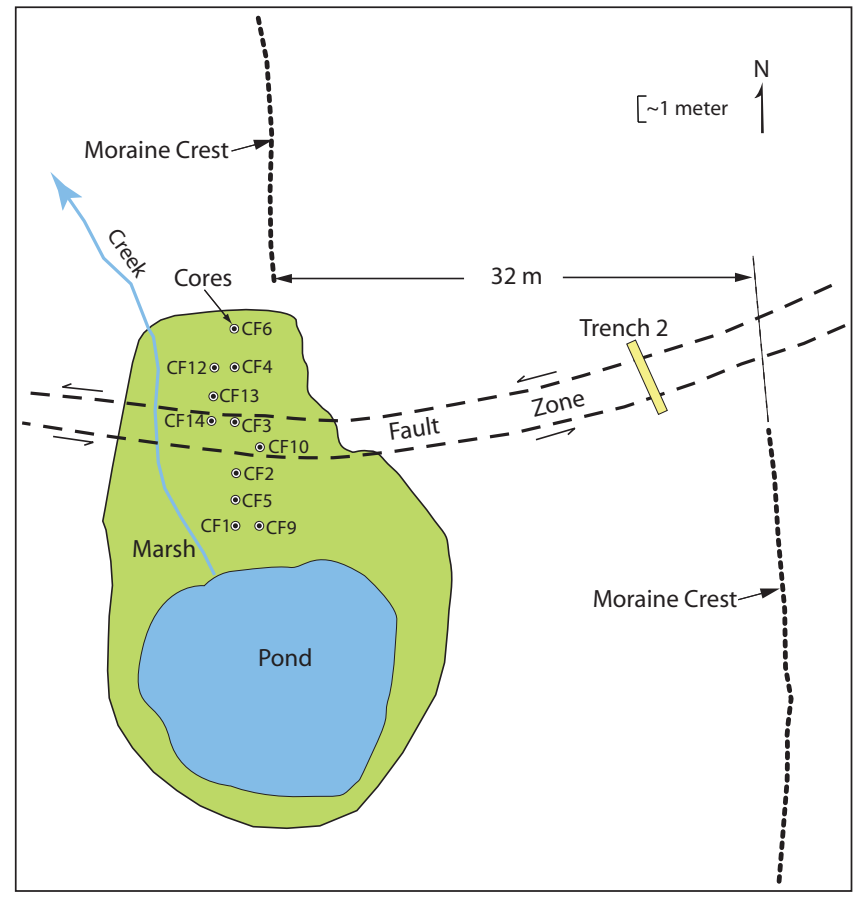

Figure 9. Sketch map showing the location of the trench and the array of cores across the Canteen fault that were obtained from the pond and adjacent marsh impounded by a shutter ridge formed by the offset Donnelly moraine. 


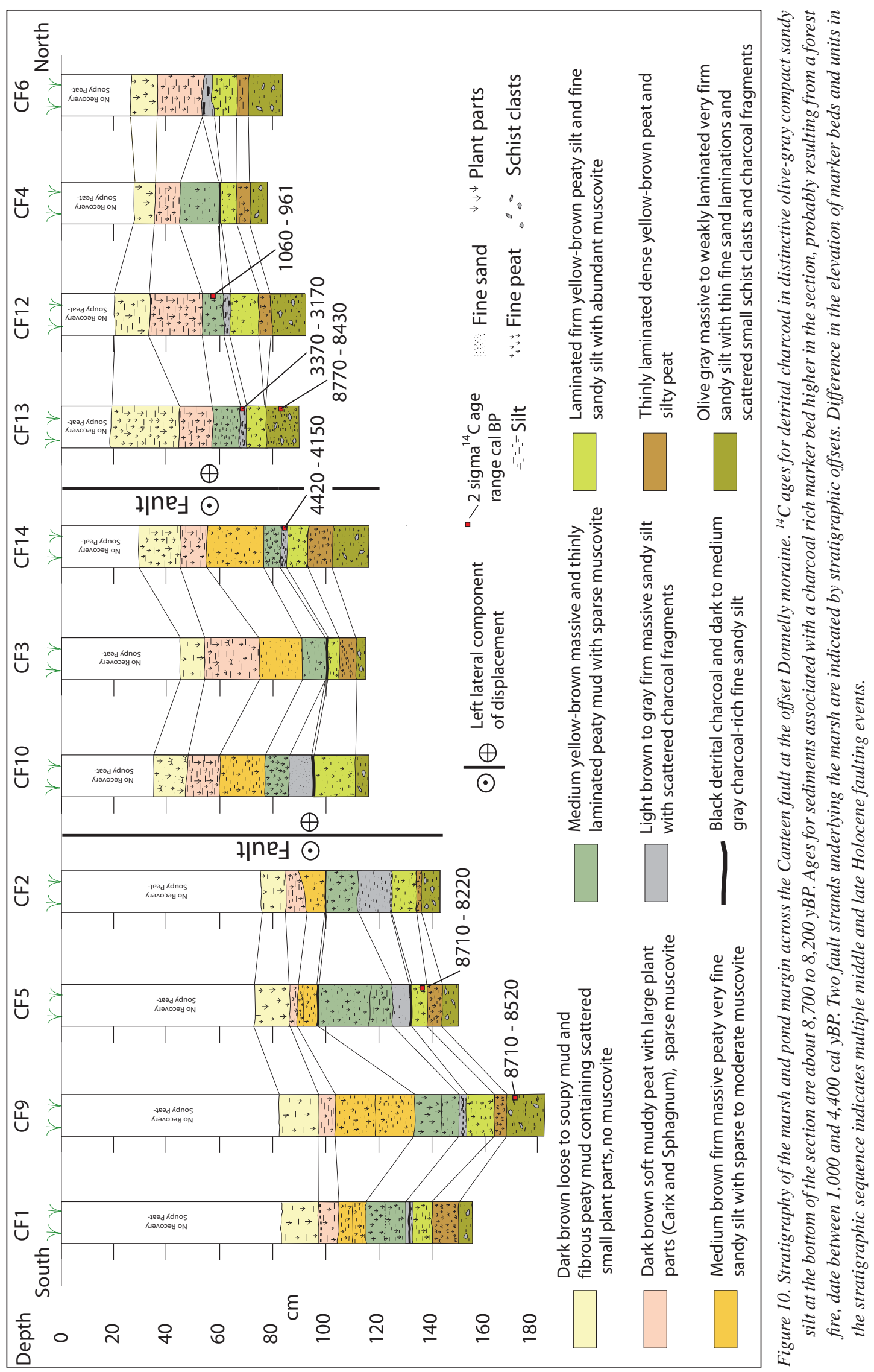




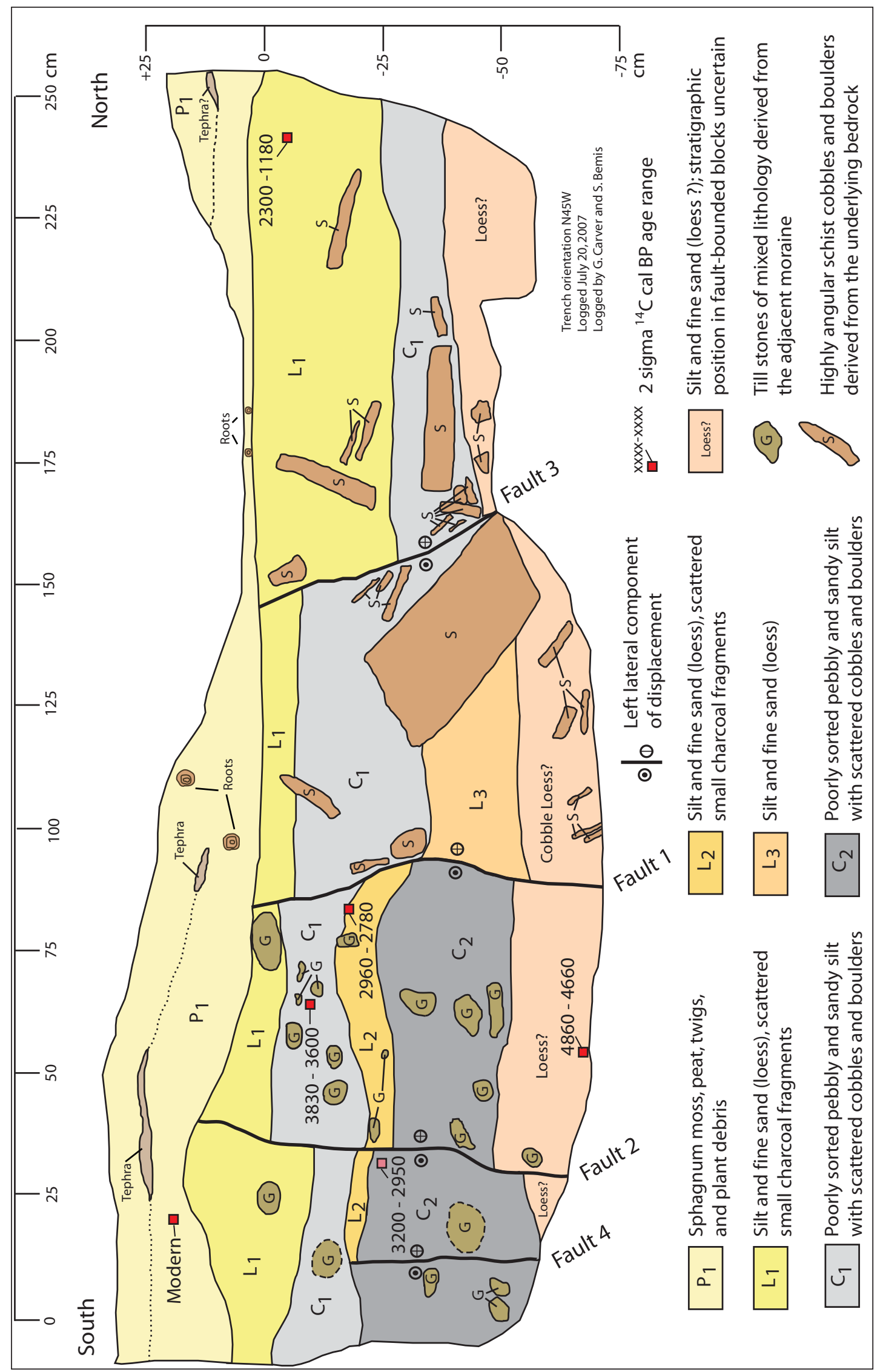

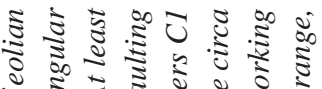

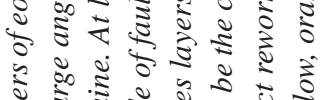
วั ป ₹

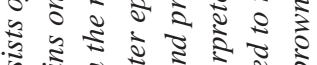
ปิ

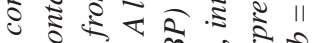
वं के

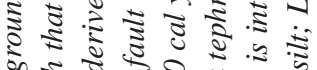

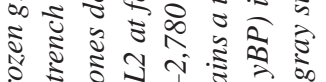
范 ป

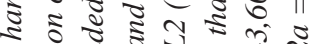
วิ ๖ั चี ป

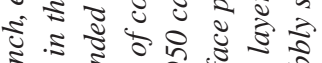

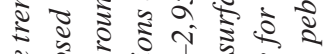
ई ฐ वे ठิ ปี

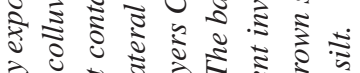

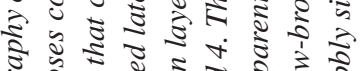
సँ.

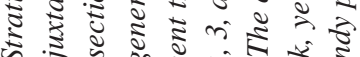
० चे

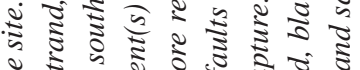
ఏँ పี हิ

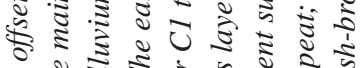
\& ङ

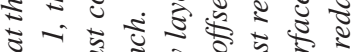
ฟ

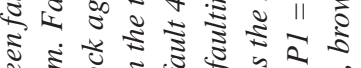
ఖँ ปี ₹

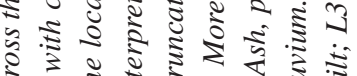

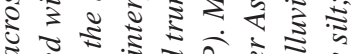

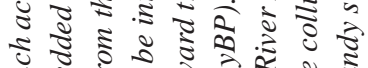
ปี

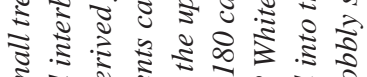

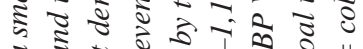

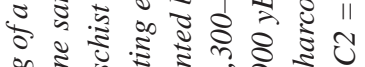
ऽ है 곤

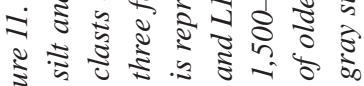




\section{DOT “T” JOHNSON FAULT}

The Dot "T" Johnson fault is a previously unrecognized, south-dipping thrust at the base of the Alaska Range foothills bordering the south side of the Tanana River valley (fig. 3). The fault extends along the south side of the Tanana River valley for more than $80 \mathrm{~km}$ from Granite Mountain to at least as far east as Dot Lake. The fault is composed of two distinct segments that are separated by large left steps on northeast-trending, left-lateral, strikeslip faults. The west end of the Granite Mountain segment ( 30 km long) is connected with the Donnelly Dome fault by the north-trending, left-lateral Panoramic fault and left-normal-oblique Granite Mountain fault. To the east, the west end of the Dot Lake segment ( 50 km long) and east end of the Granite Mountain segment are joined by the northeast-trending, left-lateral Canteen fault at the Little Gerstle River. A sublinear alignment of discontinuous scarps, truncated spur ridges, offset moraines, and vegetation lineaments along the base of the Alaska Range foothills define the Dot " $T$ " Johnson fault in the field.

In 2007 DGGS acquired helicopter-borne aeromagnetic and electromagnetic surveys of the Alaska Highway corridor (Burns and others, 2006; Solie and Burns, 2006; 2007). In the corridor, the field-mapped trace of the Dot "T" Johnson fault shows correlation with some geophysical features illustrated by the aeromagnetic and electromagnetic maps produced from the surveys (fig. 12).

\section{DOT “T” JOHNSON FAULT TRENCHES}

Between Dot Lake and Berry Creek, the Dot "T" Johnson fault forms a conspicuous south-facing scarp in late Pleistocene fluvial terrace sediments (Reger and others, 20008b). Two trenches were placed across the fault in this section, one through a "mole track" scarp at the abandoned channel of Sam Creek about $0.4 \mathrm{~km}$ south of the Alaska Highway, and a second about $4 \mathrm{~km}$ to the west across a steep 3- to 4-m-high, south-facing scarp (fig. 3). Both trenches were excavated into scarps on a loess-capped late Pleistocene Tanana River terrace. Donnelly-age jökulhlaup floods generated by collapse of an ice dam upstream at Tower Bluffs where the Robertson River glacier advanced across the Tanana River, or outburst floods from Lake Atna probably deposited the terrace (Reger and others, 2008a,b; Schmoll, 1984). Measured profiles across the Tanana River terrace and along the axis of the relatively wide floor of Sam Creek valley indicate both have been warped and tilted toward the south. The southfacing scarp on the south side of the anticline is interpreted to be the surface expression of a north-dipping back thrust on the south side of a large "pop-up" thrust wedge (fig. 13).

A third trench was dug in 2008 about 250 m west of Sears Creek along a single northeast-facing scarp. This trench revealed a shallow north-dipping fault in loosely consolidated gravel.

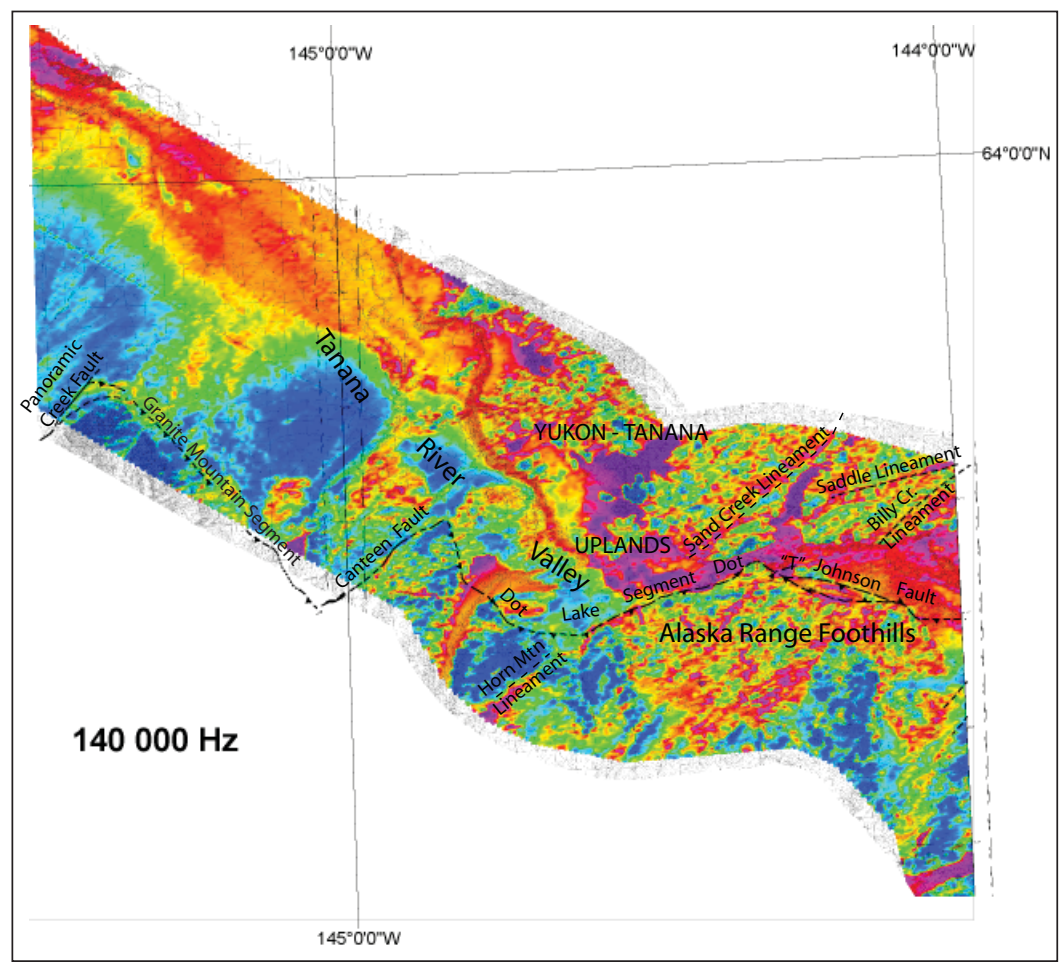

Figure 12. Electromagnetic map (EM), $140,000 \mathrm{~Hz}$, of the corridor with the Dot " $T$ " Johnson, Panoramic, and Canteen faults and the Sand Creek, Horn Mountain, Saddle, and Billy Creek lineaments (Burns and others, 2006). Image shows that sections of the Dot “ $T$ ” Johnson fault coincide with boundaries between areas with different resistivity signatures, especially along the Dot Lake segment. 


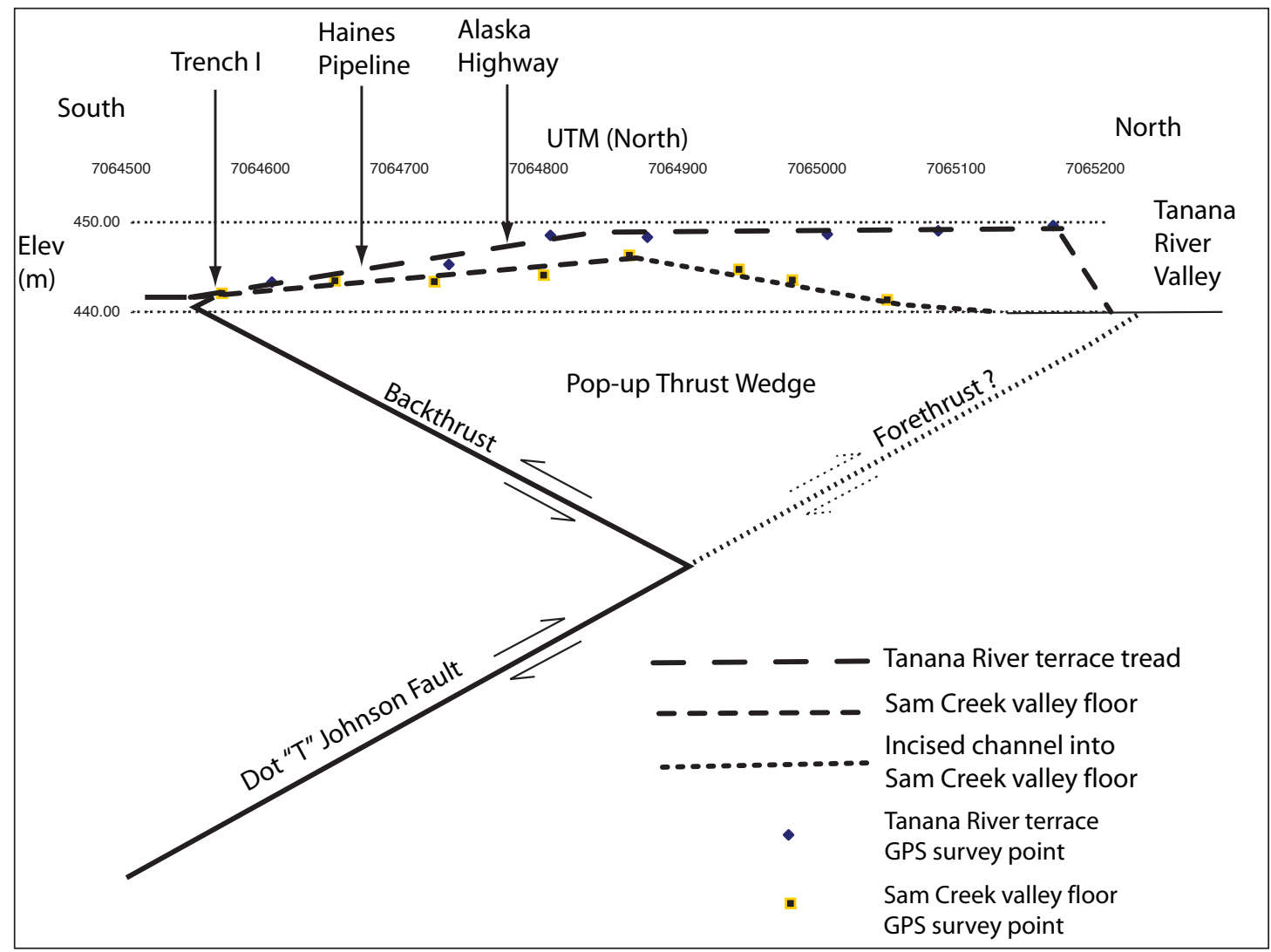

Figure 13. Profiles of the deformed Tanana River terrace and the floor of Sam Creek valley and the structural model for the pop-up thrust wedge on the Dot " $T$ " Johnson fault at trench site I. Profiles were constructed using mapping grade GPS.

\section{Dot “T” Johnson Trench I}

Trench I was excavated across a prominent 2.5- to 4-m-high mole track scarp about 400 m south of the Alaska Highway and $150 \mathrm{~m}$ west of the abandoned Sam Creek channel (fig. 14). The trench was about $18 \mathrm{~m}$ long and 1.2 to $2.4 \mathrm{~m}$ deep. The scarp is on a fluvial terrace with about $2.5 \mathrm{~m}$ of vertical separation of the terrace surface across the scarp and about $4 \mathrm{~m}$ of total relief between the down-faulted terrace and the scarp crest. Stratigraphy encountered in the trench includes well-bedded sand and gravelly sand and interbedded loess layers (figs. 15-17). The trench exposed a $\sim 20^{\circ}$ south-dipping fault terminating upward in two deposits of collapsed fault-tip rubble and associated colluvial wedges. The fault consists of several closely spaced shears in the sandy sediments and is associated with a very tightly overturned fault-propagation fold with the upper limb dismembered by the fault. Fault shears in the sand strike $\mathrm{N} 25^{\circ} \mathrm{W}$ and dip $20^{\circ} \mathrm{S}$, and the fault through the overturned loess layer in the nose of the fault propagation fold strikes $\mathrm{N}^{\circ} 6^{\circ} \mathrm{W}$ and dips $19^{\circ} \mathrm{S}$. Beneath and in front of the fault tip, at least two chaotic deposits of mixed blocks of sandy sediments and loess (CW1, CW2) are interpreted to be rubble from the collapsed overthrust hanging wall tip. The lower finger of loess (L1) and lower rubble deposit (CW1) are dragged into a tightly overturned syncline adjacent to the fault below the fault tip, and small blocks of the lower loess layer are incorporated in the upper fault tip rubble. Colluvial wedges (CW1, CW2) interbedded with thin loess layers (L1, L2) extend across the footwall from the rubble deposits. Each wedge represents a faulting event that involved more than $3 \mathrm{~m}$ of dip-slip displacement on the fault. The colluvial wedges and loess layers contain detrital charcoal fragments that were sampled for ${ }^{14} \mathrm{C}$ dating. Weak soils on and between the colluvial wedges indicate the last two events are Holocene.

Two sigma ${ }^{14} \mathrm{C}$ ages of 12,870-12,690 cal yBP (west wall) (fig. 15) and 12,100-11,720 cal yBP (east wall) (fig. 16) for detrital charcoal in the top of the finger of loess (L1) underlying the lower colluvial wedge (CW1) 


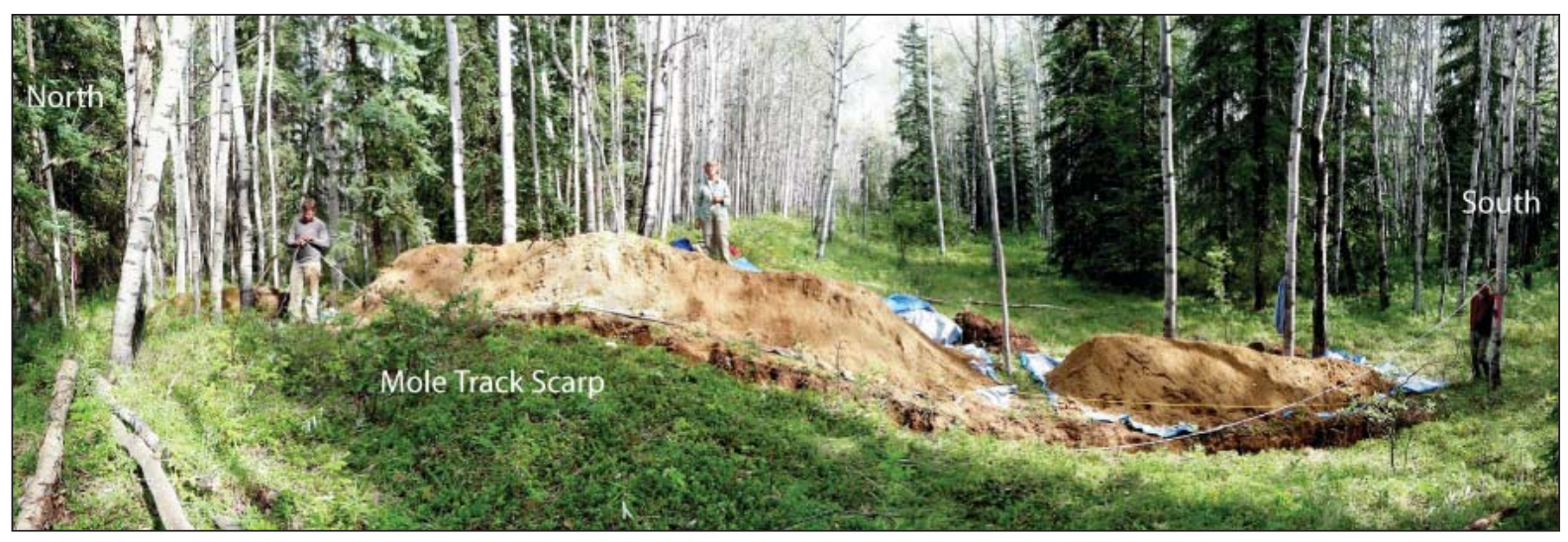

Figure 14. The "mole track" scarp on the Dot " $T$ ” Johnson fault at trench I viewed looking east. This section of the scarp exhibits a distinct "mole track" morphology indicative of a near-surface thrust wedge at the tip of a shallow-dipping thrust fault.

constrain the maximum age of the earlier faulting event. A charcoal age of 12,380-11,980 cal yBP for the center of the overlying finger of loess (L2) (fig. 15) limits the minimum age of the earlier faulting event. The maximum age of the colluvial wedge produced by the more recent episode of faulting is limited by ${ }^{14} \mathrm{C}$ ages of 9,740-9,540 and 9,290-9,010 cal yBP for charcoal in the uppermost part of the underlying loess (L2). The minimum age is unconstrained.

\section{Dot “T” Johnson Trench II}

Trench II was excavated across a well-defined, steep, south-facing scarp on a flat terrace surface about $75 \mathrm{~m}$ south of the Alaska Highway and about $4 \mathrm{~km}$ west of trench I (fig. 3). The trench was $3.5 \mathrm{~m}$ long and about 1.2 to $1.8 \mathrm{~m}$ deep. A south-dipping, low-angle backthrust of the thrust wedge was exposed (figs. 18 and 19). In the hanging wall of the fault, the trench exposed bedded sand and silt that are tightly folded and locally disrupted into chaotic rubble. The deposits are cut by a south-dipping thrust fault that displaces the loess (L1) and upper part of the underlying sand (Sm) over the loess and sand (Sc) units in the footwall. At the fault tip the hanging wall sediments are overturned. A weak cambic soil profile indicative of a Holocene age is present in the hanging wall. No datable material in suitable stratigraphic position was found in the trench.

\section{Sears Creek Trench}

A third trench on the Dot "T" Johnson fault was excavated across a 2-m-high north-facing scarp that offsets a fluvial terrace $30 \mathrm{~m}$ north of the Alaska Highway and about $250 \mathrm{~m}$ west of Sears Creek (fig. 3). This trench was located on a section where the fault runs along the base of the foothills range front and is characterized by northfacing scarps. The trench site is about $12 \mathrm{~km}$ west of trench I and west of the large pop-up thrust wedge where trenches I and II were located. The Sears Creek trench exposed bedded, poorly sorted, fine-to-medium fluvial sandy and silty gravel containing lenses of well-sorted sand and well-rounded fine matrix-free gravel (fig. 20). In the hanging wall, a 15- to 25-cm-thick layer of light yellow-brown loess caps the fluvial gravels. This loess layer thins markedly near the fault tip and, in the footwall, it remains thin and the color changes to dark grey and black.

The fluvial sediments are very loose and lack cohesion, resulting in very unstable trench sidewalls that were difficult to log. The walls were dressed and cleaned by gentle brushing with soft paintbrushes. In order to prevent sloughing of the trench walls, contacts were marked using spray paint instead of nails and flagging. Grids were placed against the walls on pole frames in order to avoid disturbing the fragile exposure. The terrace gravels are offset at the scarp by a single, low-angle thrust fault. The strike of the fault measured in the trench is $N 15^{\circ} \pm 2^{\circ} \mathrm{E}$ and the dip is $15^{\circ} \pm 2^{\circ} \mathrm{S}$. The fault zone consists of a 4- to 8-cm-thick cohesive silty sand containing many tabular pebbles. In the fault plane, the tabular pebbles are aligned parallel to the fault. The fault extends to the top of the fluvial gravels but, because the loess pinched out at the fault, the amount of offset is unclear. A thick mat of moss and decayed vegetation covers the sediments. The footwall lacked colluvial wedges and no datable material in suitable stratigraphic position to allow development of paleoseismic information was found. However, the lack of a weathering or soil profile in the fluvial sediments indicates they are Holocene in age. 


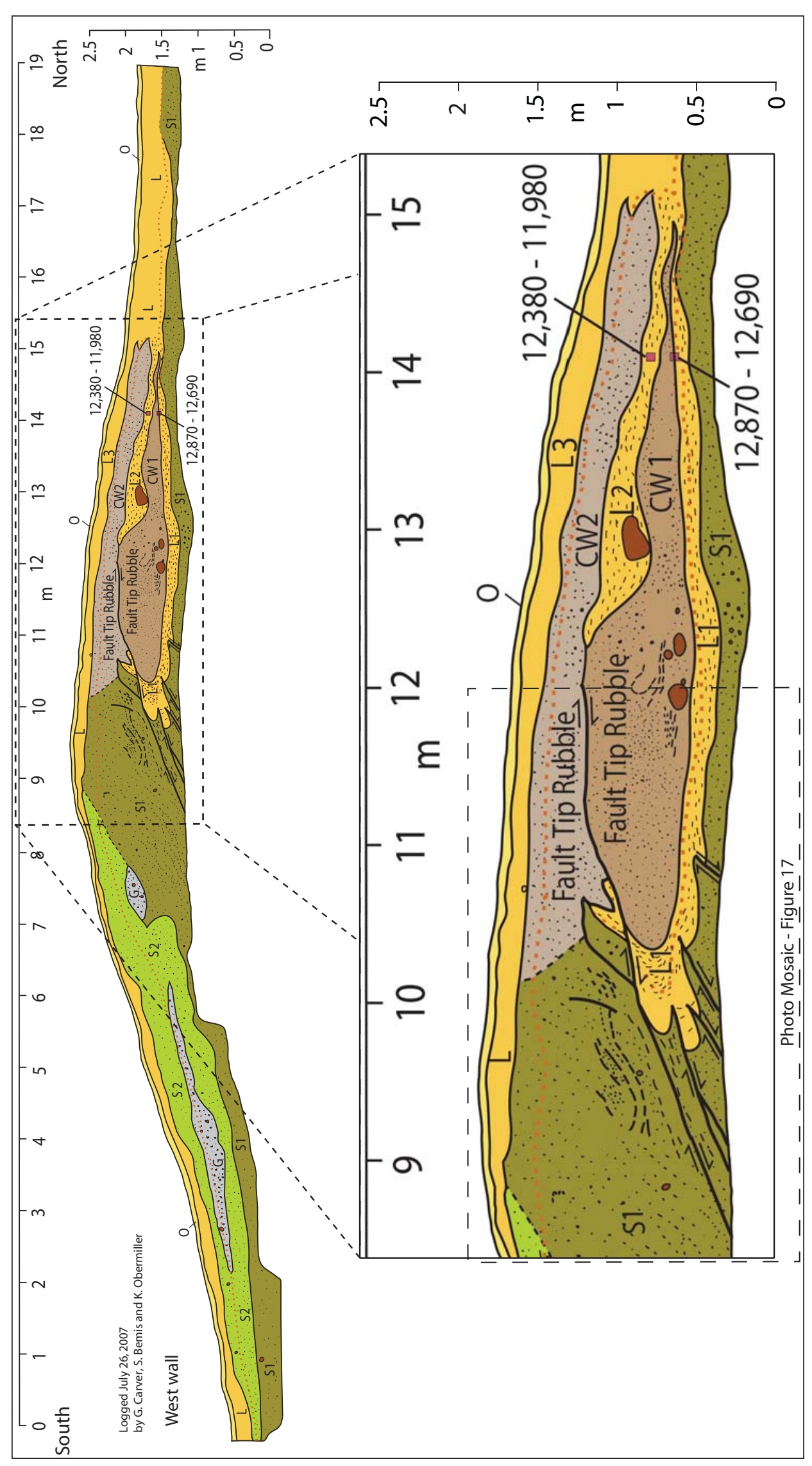

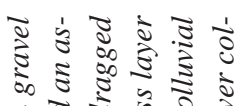

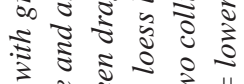

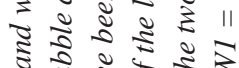
โิ

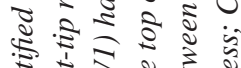
छิ

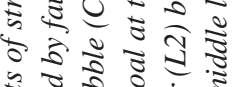

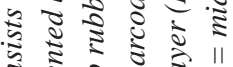

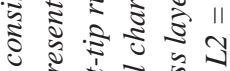
ปัँ

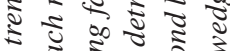

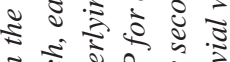

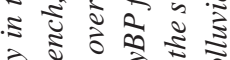
ते है 矛 :

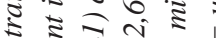
क वृ ठै $\approx$ ะ

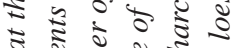

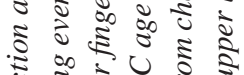

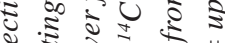

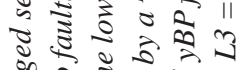
जे

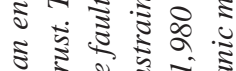
ร ฐ ฐ उั०

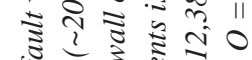

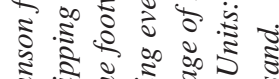
ङ : - 5 ปี th

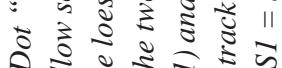
คे ईँ ฐ क బิ

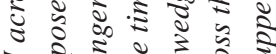

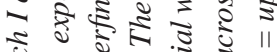

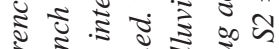

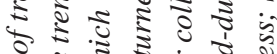

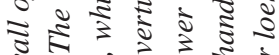

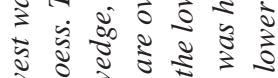
₹ శ.

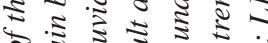

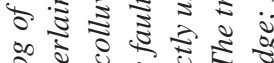

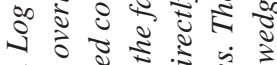

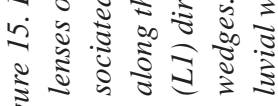




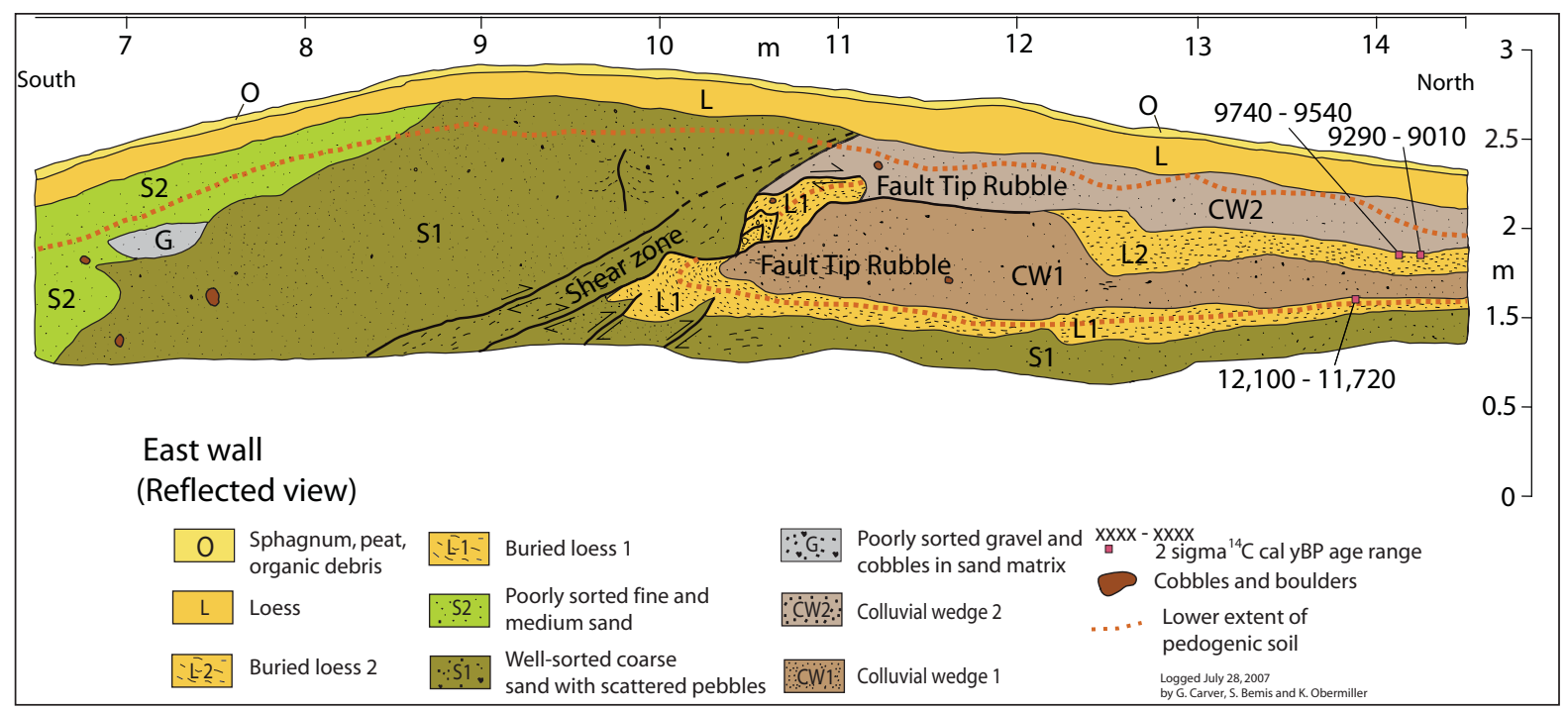

Figure 16. The east wall of trench I across the Dot " $T$ " Johnson fault shows the same fault pattern as the west wall and yielded additional ${ }^{14} \mathrm{C}$ ages of 12,100-11,700 cal yBP from detrital charcoal at the top of the layer of loess (L1) underlying the older colluvial wedge (CW1) and 9,740-9,540 and 9,290-9,010 cal yBP for detrital charcoal at the top of the second loess layer (L2) between the two colluvial wedges. The trench was hand-dug across the mole track ridge.

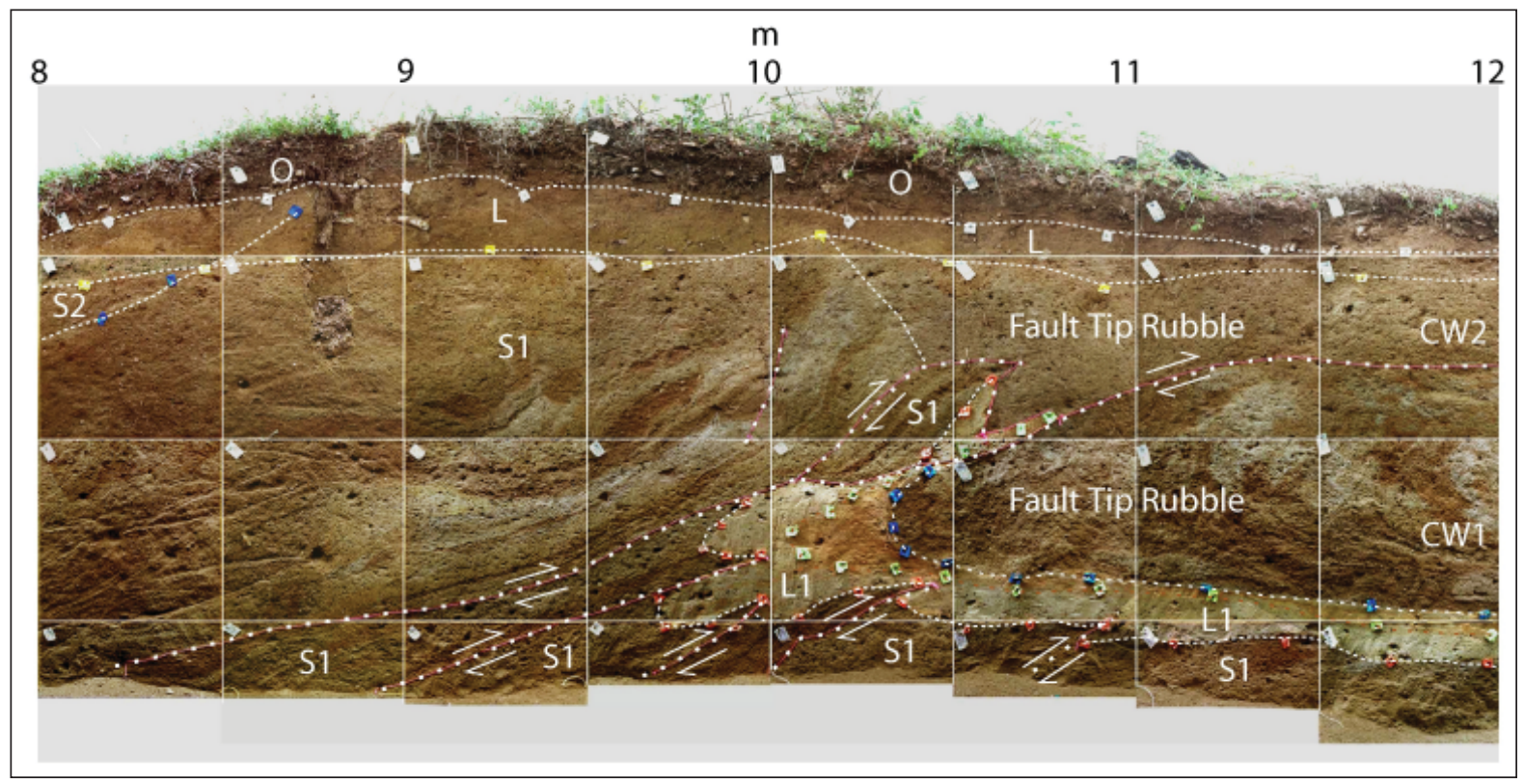

Figure 17. Photo mosaic of the west wall of trench I. Loess layer L, offset by several small subsidiary thrusts, can be seen in the footwall of the fault. The top of the loess layer is iron stained. The photo mosaic clearly shows the faulted nose of the tight fold and overturning of the loess bed at the fault. Grid spacing on the trench wall is $0.5 \mathrm{~m}$. Trench was hand-dug across mole track ridge. $\mathrm{O}=$ organic mat; L3 = upper loess; CW2 = upper colluvial wedge; L2 = middle loess; CW1 = lower colluvial wedge; L1 = lower loess; S2 = upper sand; S1 = lower sand. 


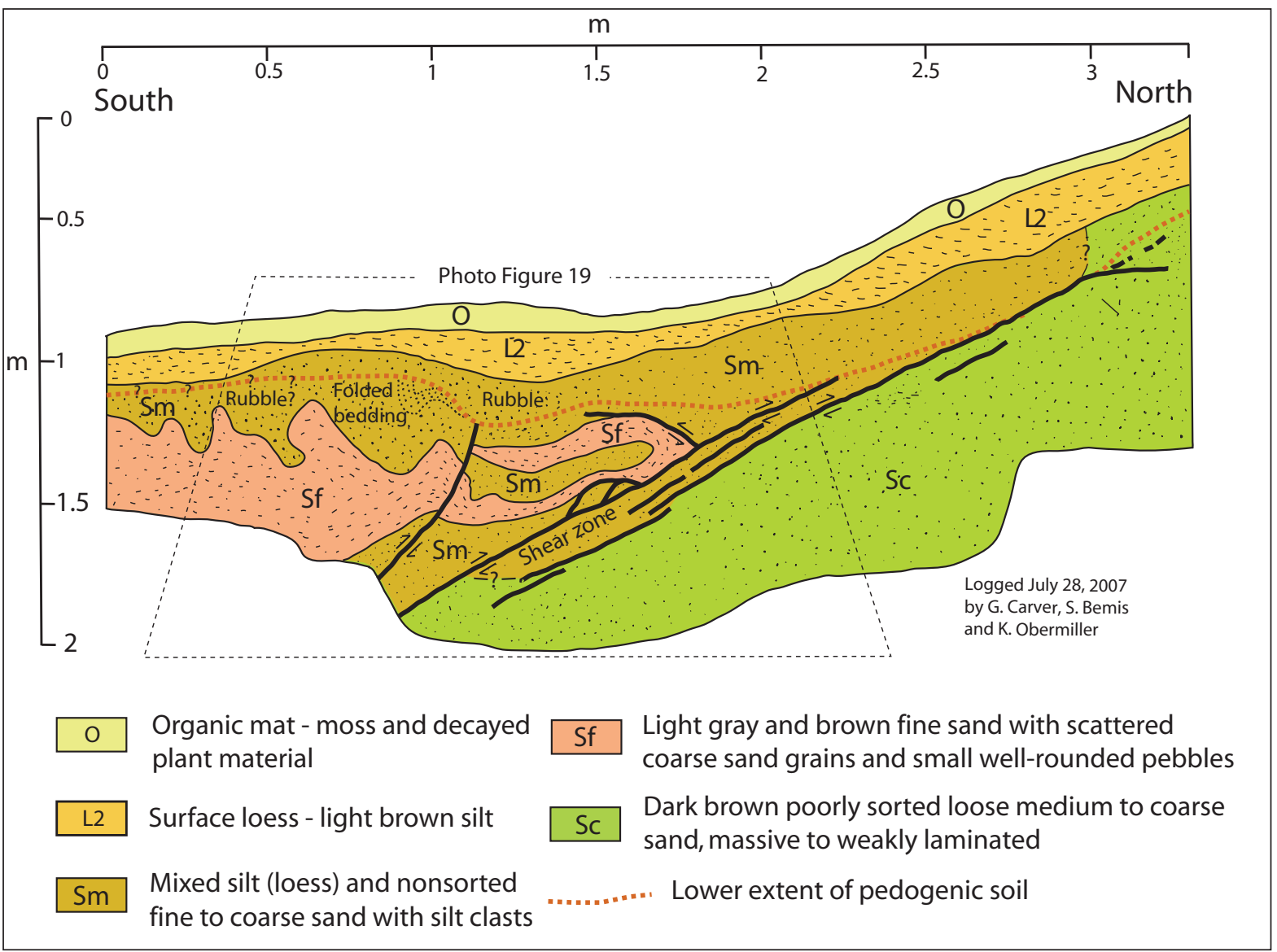

Figure 18. Log of the west wall of trench II on the Dot " $T$ ”" Johnson fault. Like trench I, trench II exposed a south-dipping, low-angle thrust fault indicative of a near-surface thrust wedge. The stratigraphy in the trench consists of stratified coarse sand in the footwall, and fine to coarse poorly sorted sand and silt in the hanging wall. The sands are capped by loess. The sand and silt in the hanging wall is tightly folded and at the fault tip is overturned. No datable material was found in the trench. Strike of shear zone is $N 90^{\circ} \mathrm{E}$ and dip is between $24^{\circ}$ and $33^{\circ} \mathrm{S}$.

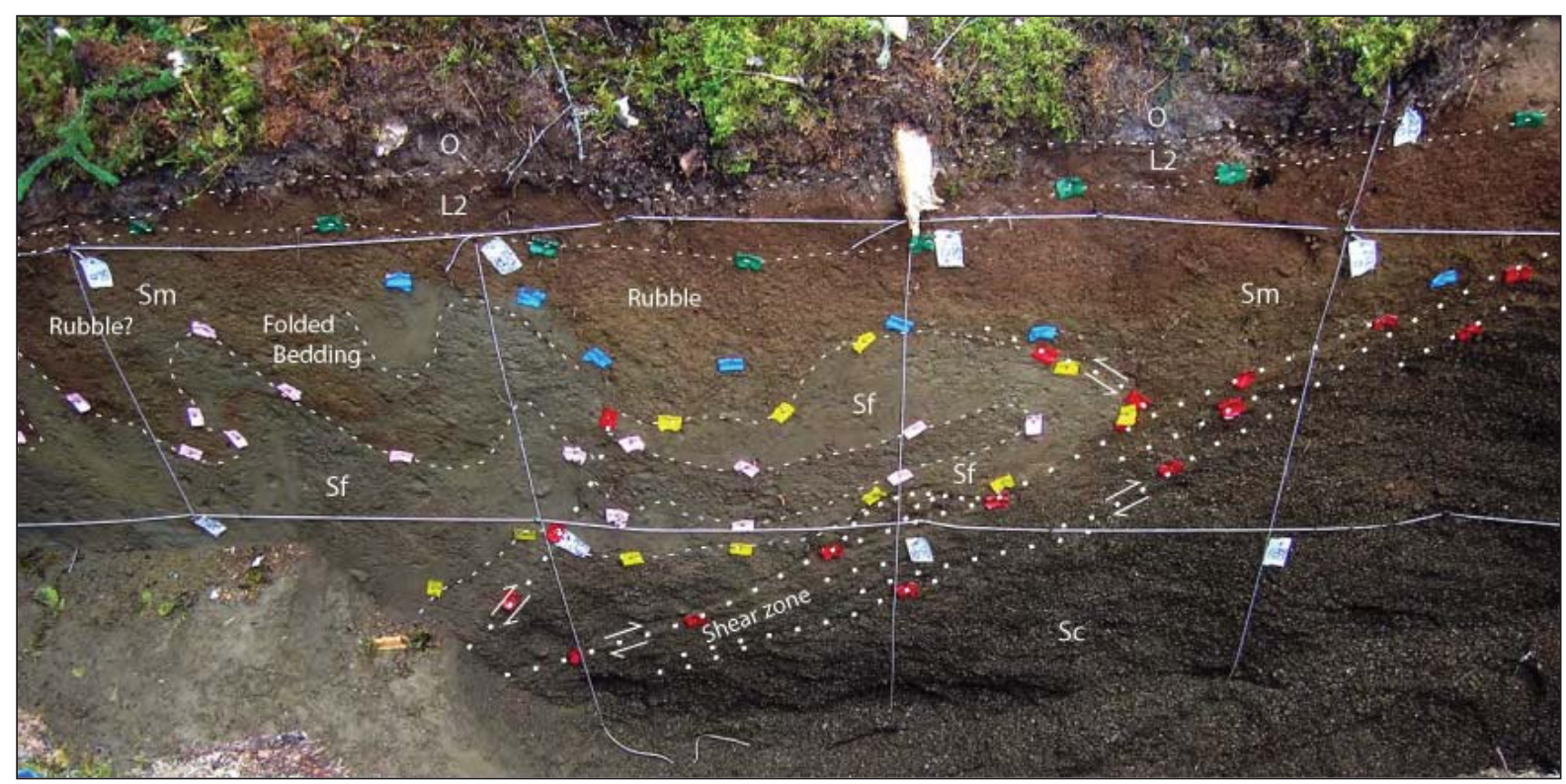

Figure 19. Photograph of the west wall of trench II on the Dot " $T$ ”" Johnson fault. Grid spacing is $1 \mathrm{~m}$. Unit labels as shown in figure 18. Strike of shear zone is $N 90^{\circ} \mathrm{E}$ and dip is between $24^{\circ}$ and $33^{\circ} \mathrm{S}$. 


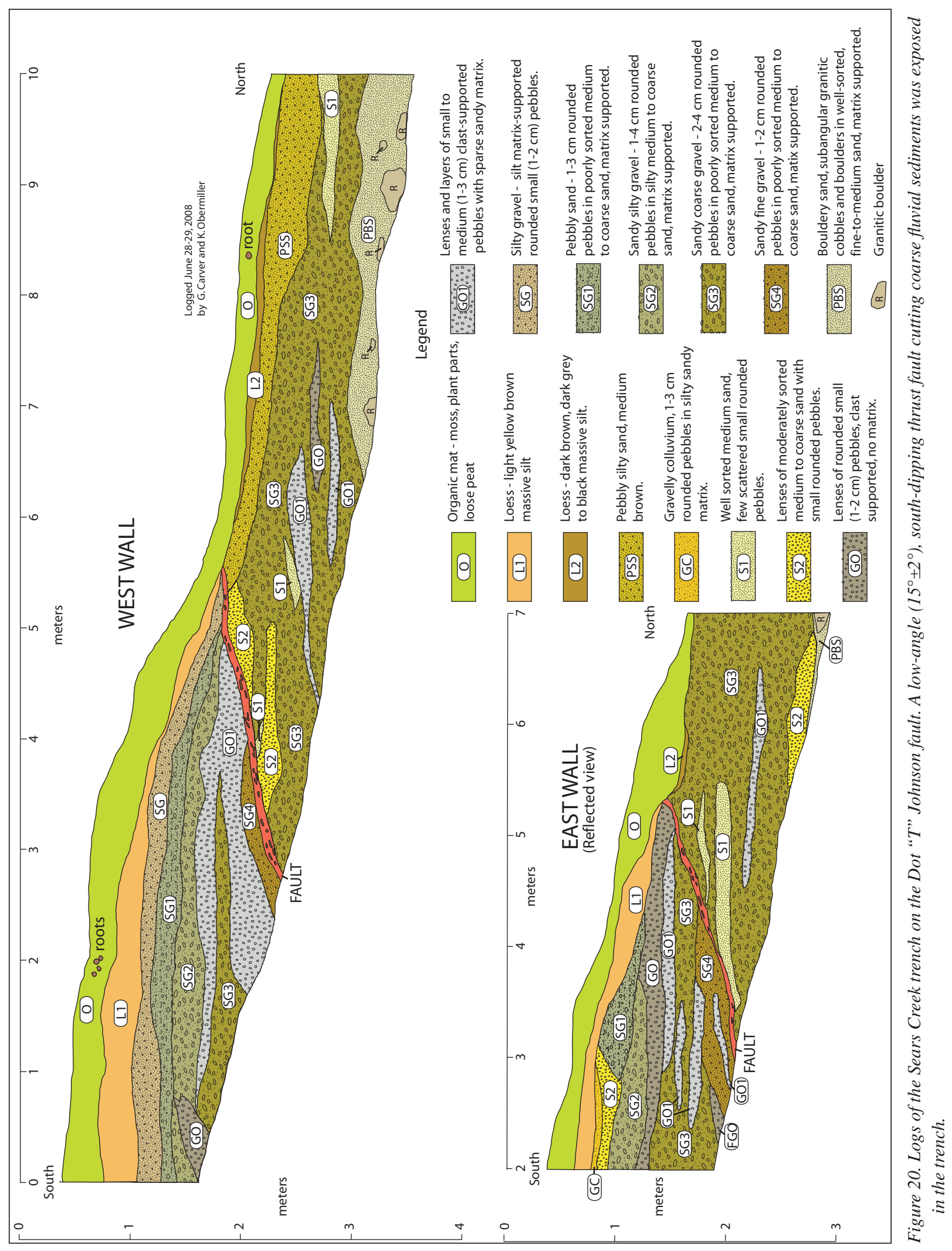


In the footwall under the fluvial gravels, massive well-sorted, fine-to-medium sand containing subangular granitic boulders (PBS) was exposed in the bottom of the trench (fig. 20). A similar deposit is exposed in the hanging wall in the road cut of the Alaska Highway about $30 \mathrm{~m}$ south of the trench (fig. 21). In the road cut, the boulder-bearing sand overlies granitic bedrock that was the source of the boulders. Adjacent to the trench, the top of the road cut was graded but nearby fluvial gravels cap the sand and boulders. A surveyed profile from the trench to the road cut shows a minimum of $3.2 \mathrm{~m}$ of vertical separation of the boulder sand-fluvial gravel contact. If this elevation difference is a result of faulting, the dip-slip displacement on the fault after deposition of the massive sand and boulder unit (PBS) is $12.4 \mathrm{~m}$. The scarp is about $2 \mathrm{~m}$ high, reflecting about $7.7 \mathrm{~m}$ of fault offset since the fluvial sediments that comprise the terrace were deposited.

\section{PANORAMIC FAULT}

The Panoramic fault branches from the Granite Mountain fault on the northwest side of Granite Mountain and offsets a broad alluvial plain composed of late Pleistocene outwash and Holocene alluvium on the south side of the Tanana River valley (fig. 3). Profiles surveyed across the fault show the alluvial surface is vertically offset 2 to $3 \mathrm{~m}$ upward on the valley side (fig. 22). Panoramic Creek follows the linear path of the fault trace across the northward drainage from Granite Mountain. The Panoramic and associated Granite Mountain faults connect the Holocene Donnelly Dome fault with a poorly defined thrust and large late Cenozoic monocline along the northeast flank of Granite Mountain. The airborne electromagnetic resistivity survey data show evidence for a fault in this area, which dips south at a high angle where profiled in the upper $100 \mathrm{~m}$ (Solie and Burns, 2006).

\section{SAND CREEK LINEAMENT}

The Sand Creek lineament is defined by the linear course of Sand Creek and a prominent geophysical lineament on the aeromagnetic and electromagnetic maps of Sand Creek valley (fig. 12). Extensive helicopter reconnaissance of the Sand Creek valley did not reveal any compelling evidence to indicate geologically youthful faulting, but the linear valley, its northeast orientation, and prominent linear geophysical anomaly warrant consideration of additional study of this lineament. Helicopter reconnaissance identified two linear features on the lineament that were investigated for evidence of youthful surface faulting: (1) a series of scarp-like features on the noses of spur ridges along the east side of the upper Sand Creek valley and (2) a linear vegetation boundary between black spruce forest to the east and hardwood forest to the west in the central part of the valley (fig. 23). However, field reconnaissance found no evidence of a scarp associated with the vegetation boundary. A surveyed profile across one of the scarp-like features in the upper part of the valley revealed no vertical offset of the crest of the spur ridge, indicating the scarp-like features are the result of differential erosion of an inactive linear bedrock fault and not youthful surface faulting of the spur ridges (figs. 24 and 25). Between spur ridges, tributary valleys to Sand Creek are filled with alluvium that is probably Holocene in age. No scarps offset the broad planar alluvial surfaces in the tributary valleys on line with the spur ridge scarp-like features. We conclude that the Sand Creek lineament is the expression of an old inactive fault and differential erosion along this fault has produced the scarp-like spur ridge features and controlled the location and linear trend of Sand Creek valley.

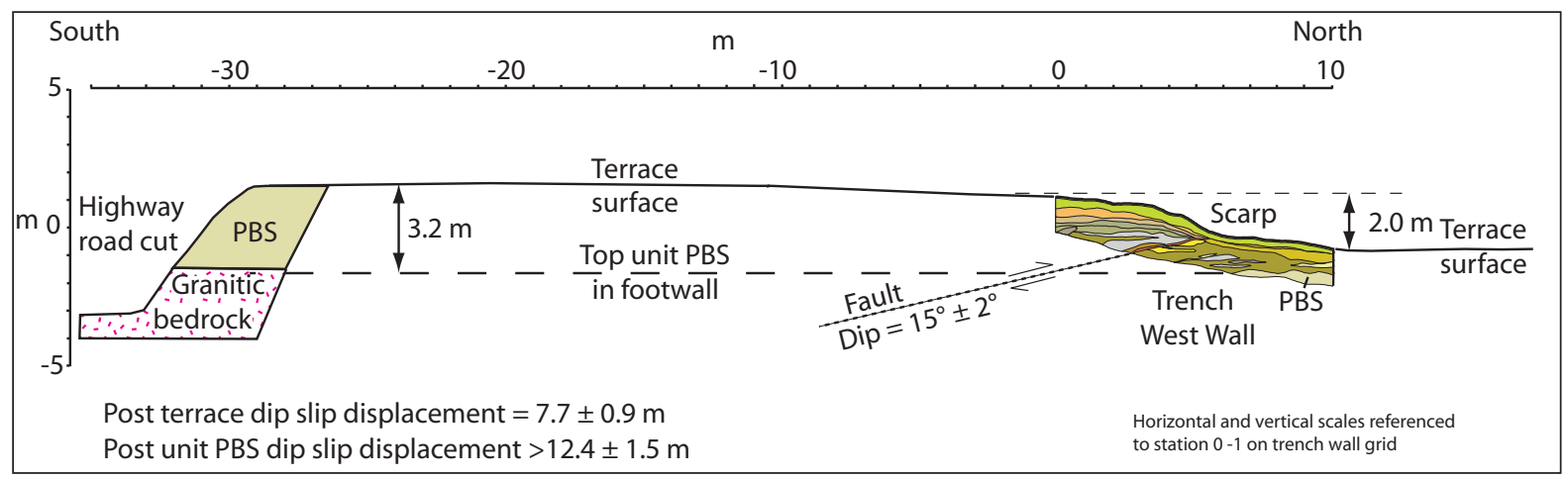

Figure 21. Cross-section showing a measured scarp profile, trench, and adjacent highway road cut at the Sears Creek trench site. 


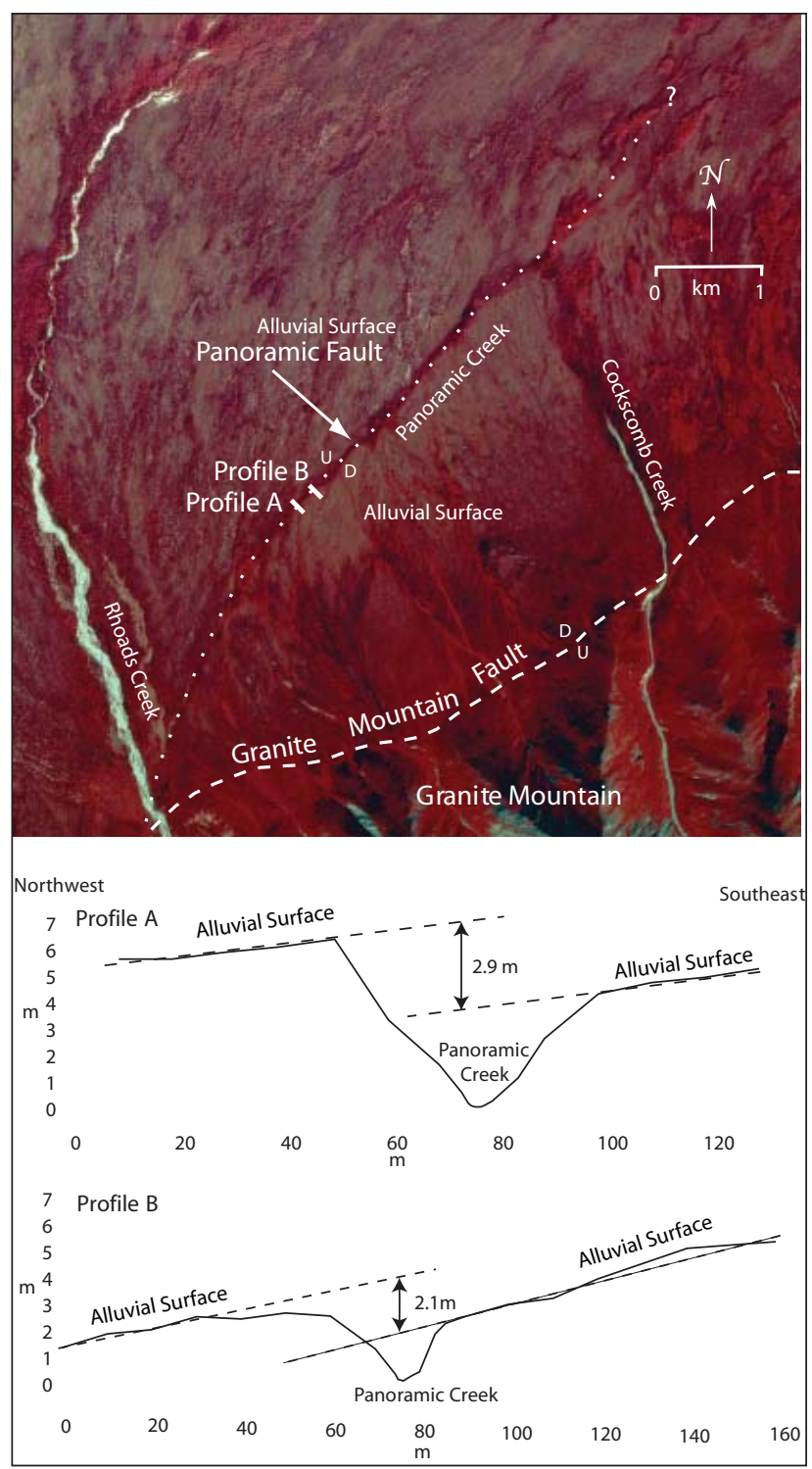

Figure 22 (left). Color infrared vertical air photo showing the trace of the Panoramic fault, which branches off of the Granite Mountain fault on the northwest flank of Granite Mountain and trends northwest across a broad alluvial surface. Two profiles of the surface across the fault show about 2 to $3 \mathrm{~m}$ of valley-side up displacement. The linearity of the fault and its northwest trend suggest it has a significant left lateral component.

Figure 23 (below). The prominent vegetation line on the Sand Creek lineament in the central part of the Sand Creek valley viewed from the south. Field reconnaissance found no scarp or evidence of Holocene surface faulting associated with the vegetation line.

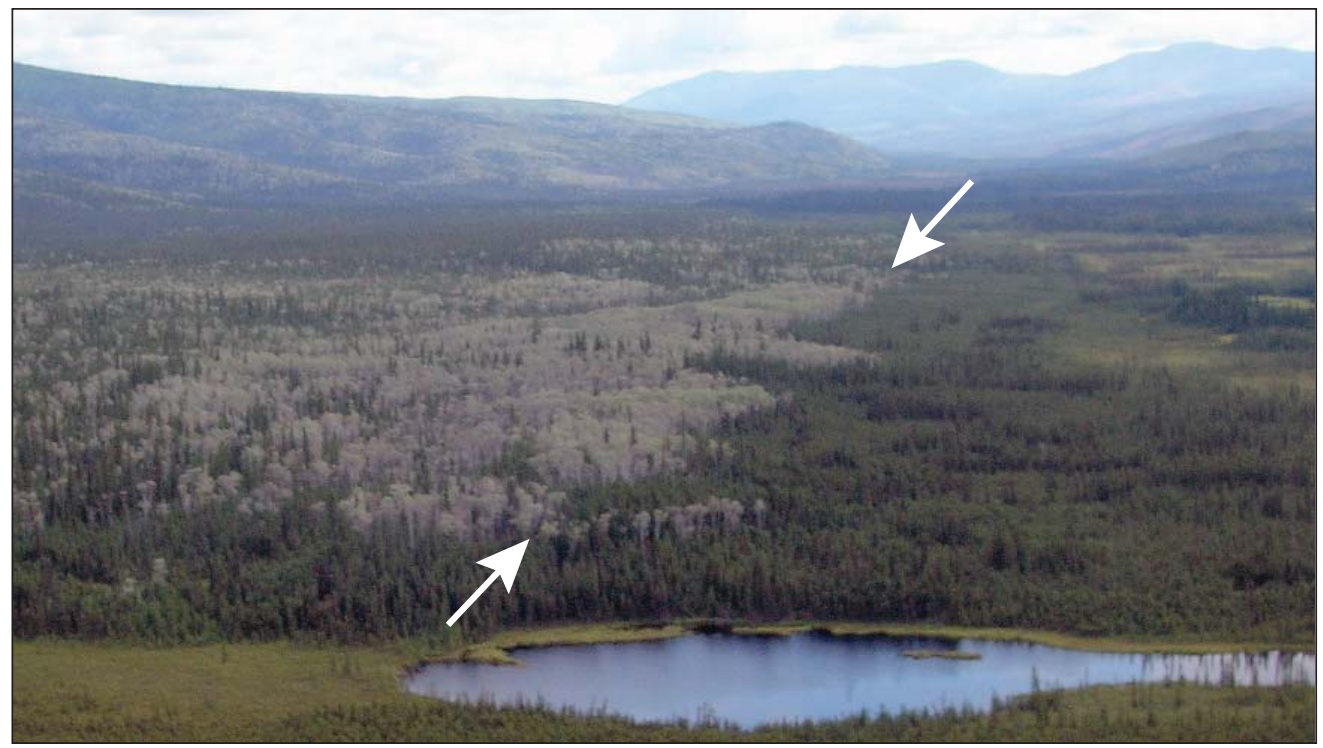




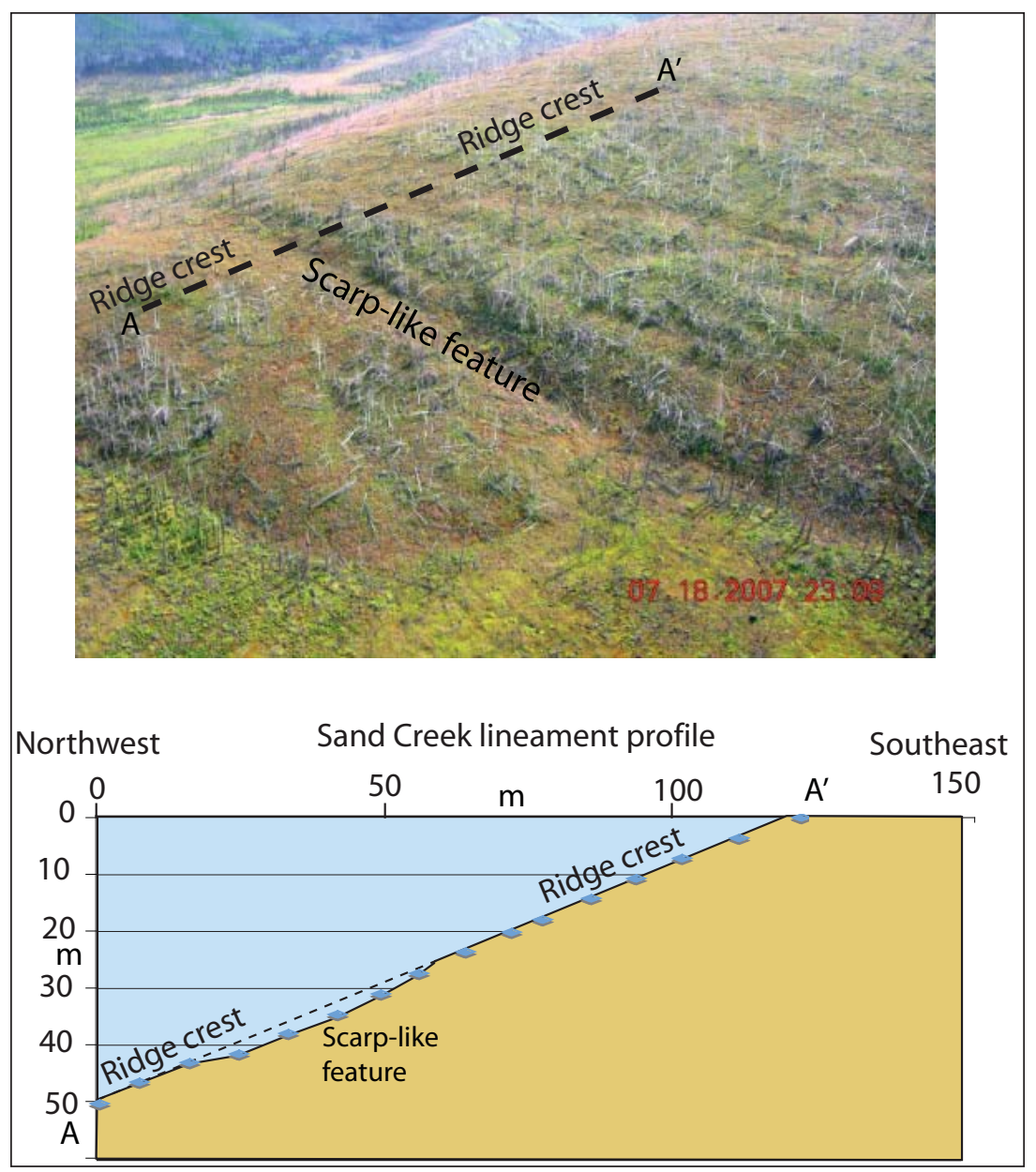

Figure 24. Oblique air photo (upper) and surveyed profile (lower) across a scarp-like feature on the nose of a spur ridge in the upper part of Sand Creek valley along the Sand Creek lineament. The view is from the southwest looking northeast. The profile along the crest of the ridge shows no offset across the scarp-like feature.

\section{HORN MOUNTAIN LINEAMENT}

The Horn Mountain lineament is marked by a prominent linear geophysical anomaly on the aeromagnetic and electromagnetic survey maps and is shown on the Neotectonic Map of Alaska (Plafker and others, 1994) as a late Pleistocene fault (fig. 3). The lineament also generally corresponds with the western margin of outcrops of the Tertiary Usibelli Group sediments on the Macomb Plateau (fig. 4). Bedrock mapping for the corridor geologic framework assessment identified a fault characterized by mylonitic and recrystallized textures in plutonic rocks on the plateau that generally corresponds with the lineament. This fault is interpreted as an old structure that formed at depth prior to and during uplift of the plateau and is not associated with youthful active surface faulting.

Helicopter and surface reconnaissance of the lineament found no evidence of geologically youthful faulting along the lineament. The Macomb Plateau surface crosses the lineament without a scarp or evidence of vertical offset. The plateau, interpreted to be the exhumed pre-Usibelli Group erosion surface, was not glaciated but was exposed to strong winds and intense periglacial processes during the Donnelly glaciation. Fields of locally derived granitic boulders up to $10 \mathrm{~m}$ long, the result of ground-ice wedging, mantle most of the plateau. The surfaces of the boulders are deeply weathered, pitted, and encrusted with lichens, evidence that the periglacial processes are presently inactive and have been inactive during the Holocene. Thus we conclude no surface faulting associated with the Horn Mountain lineament has occurred during the Holocene.

\section{BEAR CREEK WEST LINEAMENT}

The Bear Creek West lineament was identified on low-altitude black and white air photos as a north-trending photo lineament crossing the Alaska Highway about $800 \mathrm{~m}$ west of Bear Creek (fig. 3). Field reconnaissance revealed the photo lineament coincides with a 0.5 -m-high, west-facing scarp on a gently sloping outwash terrace. 


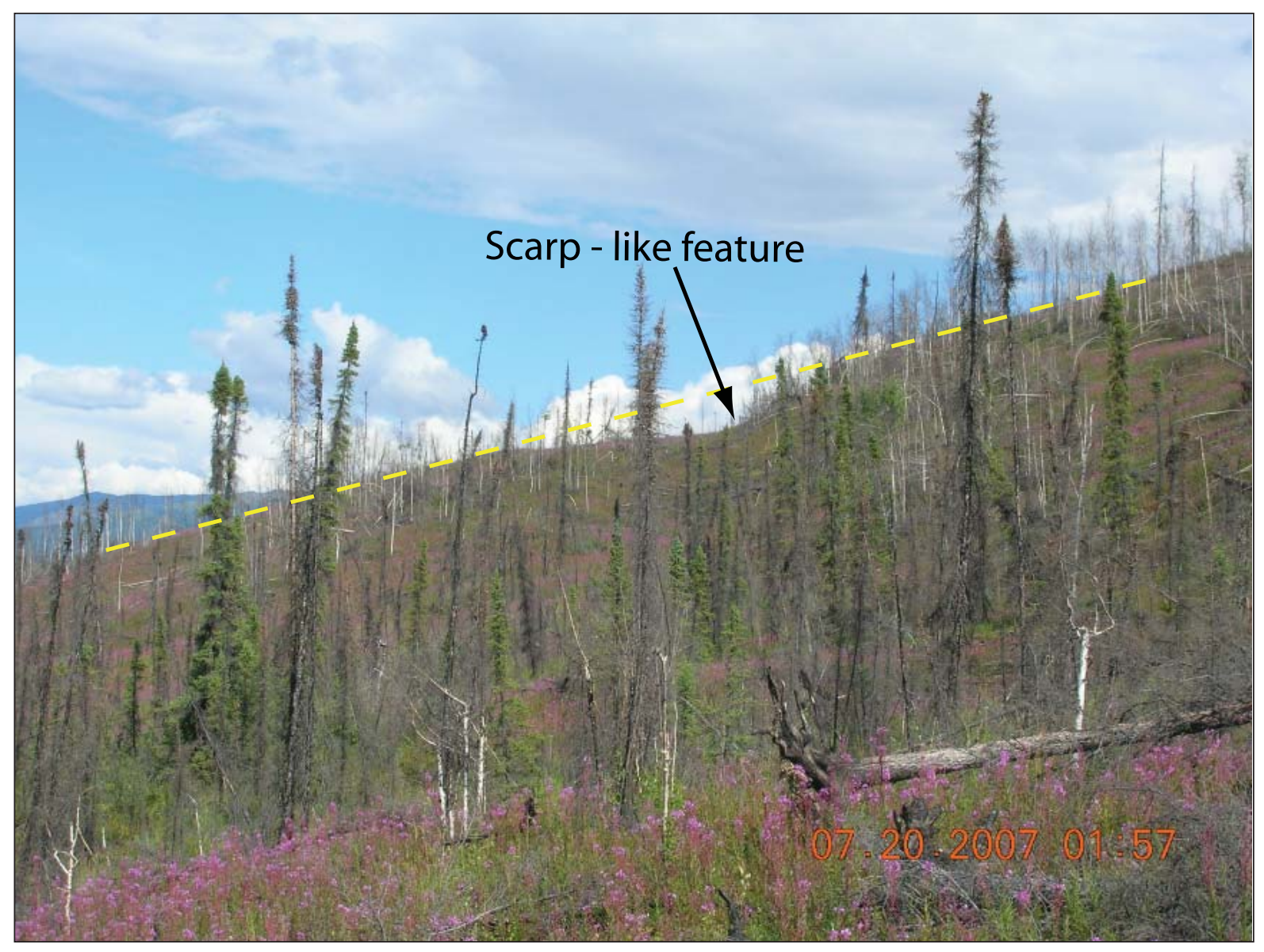

Figure 25. Photograph looking northeast along the scarp-like feature shown in figure 24. The yellow dashed line across the scarp-like feature is a projection of the ridge crest and is not offset.

A small exploratory test trench excavated across the scarp exposed a boulder and cobble diamicton interpreted to be Donnelly outwash. The deposit lacks stratification except for a few short $(30-50 \mathrm{~cm})$, poorly defined sandy and silty lenses. A loess layer about $10 \mathrm{~cm}$ thick on the top of the scarp and 20 to $25 \mathrm{~cm}$ thick at the base of the scarp covers the outwash. A well-developed cambic soil profile about $50 \mathrm{~cm}$ thick indicative of a post-Donnelly soil is developed in the loess and upper part of the outwash. The trench exposed no sediments useful to evaluate the presence or absence of a fault and was backfilled without detailed logging.

\section{CONCLUSIONS}

Mapping and paleoseismic field investigations of potential active faults in and near the western part of the Alaska Highway corridor by the Alaska Division of Geological \& Geophysical Surveys in 2006, 2007, and 2008 have documented late Pleistocene and Holocene displacements on the Panoramic, Canteen, Dot "T" Johnson, and Billy Creek faults. The Dot "T" Johnson fault is a major thrust fault that structurally defines the northern margin of the Alaska Range foothills through the upper Tanana River valley. This fault has two distinct segments separated by a large left step, the left-lateral Canteen fault. The west end of the Dot "T" Johnson fault joins the eastern end of the Donnelly Dome fault along the left-normal-oblique Granite Mountain and left-lateral Panoramic faults at another large left step. The Dot "T" Johnson fault represents the eastern extension of the Northern Foothills Fold and Thrust Belt (NFFTB). Paleoseismic information from trenches across the Dot Lake segment of the Dot "T" Johnson and Canteen faults shows that both faults ruptured multiple times during the latest Pleistocene and Holocene. ${ }^{14} \mathrm{C}$ ages for faulting events indicate recurrence intervals for surface faulting of about 2,000 to 3,000 yrs. The Dot Lake segment is about $50 \mathrm{~km}$ long and trench I across this segment of the fault showed paleodisplacements of at least $3 \mathrm{~m}$. Assuming this entire segment ruptured and produced about $3 \mathrm{~m}$ of dip-slip displacement, the resulting 
earthquake likely would be in the range of M 7 to 7.25 (Wells and Coppersmith, 1994).

The Billy Creek fault, north of the Tanana River in the Yukon-Tanana uplands, is a northeast-trending leftlateral normal-oblique-slip fault that has experienced multiple episodes of late Quaternary surface displacement, with at least the most recent in the Holocene. The fault is at least $35 \mathrm{~km}$ long. Although its location is well defined along most of its length to within a couple kilometers of the northern boundary of the corridor, its location in the corridor is not known.

These faults constitute potential surface faulting hazards to proposed development in the corridor and may be future sources of locally generated strong ground motion and associated seismic hazards including earthquakegenerated liquefaction and seismically triggered slope failures. To ensure seismic hazards associated with the faults documented in this study are appropriately mitigated, additional detailed regional and site-specific studies will be required to develop information necessary for the routing, design, construction, and operation of future facilities in the Alaska Highway corridor, including the proposed Alaska-Canada natural gas pipeline and the Alaska Railroad through Canada.

\section{ACKNOWLEDGMENTS}

This project is funded by the State of Alaska and managed by the Alaska Division of Geological \& Geophysical Surveys. We thank Ray J. Weldon (University of Oregon) for his careful and constructive reviews of the Billy Creek, Canteen, and Dot “T” Johnson I and II trenches, and Peter Haeussler (USGS) and Gordon Seitz (San Diego State University) for their insightful reviews of the Sears Creek trench. Valuable discussions with Richard D. Reger (Reger Geologic Consulting), Robert F. Swenson (DGGS Director and State Geologist), and Rodney A. Combellick (DGGS Deputy Director) are also gratefully acknowledged. Richard D. Reger reviewed the manuscript, and we appreciate his constructive and insightful comments.

\section{REFERENCES CITED}

Albanese, M.D., 1980, The geology of three extrusive bodies in the central Alaska Range: Fairbanks, Alaska, University of Alaska Fairbanks, unpublished M.S. thesis, $101 \mathrm{p}$.

Begét, J.E., 2001, Continuous Late Quaternary proxy climate records from loess in Beringia: Quaternary Science Reviews, v. 20, p. 499-507.

Begét, J.E., and Keskinen, M.J., 1991, The Stampede Tephra; A middle Pleistocene marker bed in glacial and eolian deposits of central Alaska: Canadian Journal of Earth Sciences, v. 28, no. 7, p. 991-1002.

2003, Trace-element geochemistry of individual glass shards of the Old Crow tephra and the age of the Delta glaciation, central Alaska: Quaternary Research, v. 60, no. 1, p. 63-69.

Bemis, S.P., 2004, Neotectonic framework of the north-central Alaska Range foothills: Fairbanks, Alaska, University of Alaska Fairbanks, unpublished M.S. thesis, 142 p.

Bemis, S.P.. and Wallace, W.K., 2007, Neotectonic framework of the north-central Alaska Range foothills, in Ridgeway, K.D., Trop, J.M., Glen, M.G., and O’Neill, J.M., eds., Tectonic growth of a collisional continental margin; Crustal evolution of southern Alaska: Geological Society of America Special Paper 431, p. 549-572.

Bemis, S.P., Weldon, R.J., and Burns, P.A.C., 2005, Progress in characterizing active faults of the northern flank of the Alaska Range [abs.]: Boulder, CO, Geological Society of America Abstracts with Programs, v. 37, no. 7, p. 78.

Briner, J.P., Kaufman, D.S., Manley, W.F., Finkel, R.C., and Caffee, M.W., 2005, Cosmogenic exposure dating of late Pleistocene moraine stabilization in Alaska: Geological Society of America Bulletin, v. 117, no. 7/8, p. 1,108-1,120.

Bronk Ramsey, C., 1995, Radiocarbon calibration and analysis of stratigraphy; The OxCal program: Radiocarbon, v. 37, no. 2, p. 425-430.

\section{3.}

Burns, L.E., Fugro Airborne Surveys, and Stevens Exploration Management Corp., 2006, Line, grid, and vector data, and plot files for the airborne geophysical survey of the Alaska Highway corridor, east-central Alaska: Alaska Division of Geological \& Geophysical Surveys GPR 2006-6, 1 DVD.

Carter, L.D., 1980, Tertiary tillites(?) on the northeast flank of Granite Mountain, central Alaska Range, in Short Notes on Alaskan Geology, 1979-80: Alaska Division of Geological \& Geophysical Surveys Geologic Report 63, p. 23-27. 
Carver, Gary, Plafker, George, Metz, Mike, Cluff, Lloyd, Slemmons, Burt, Johnson, Elden, Roddick, Jim, and Sorensen, Steve, 2004, Surface rupture on the Denali fault interpreted from tree damage during the 1912 Delta River Mw 7.2-7.4 earthquake; Implications for the 2002 Denali fault earthquake slip distribution, in Rowe, C.A., Christensen, D., and Carver, G.A., eds., The 2002 Denali fault earthquake sequence, dedicated issue: Bulletin of the Seismological Society of America, v. 94, no. 6B, p. S58-S71.

Carver, G., Plafker, G., Metz, M., Cluff, L., Bemis, S., Roddick. J., Redington, J., and Sorensen, S., 2006, Late Quaternary growth of thrust faults and associated folds in the eastern part of the Northern Foothills Fold and Thrust Belt, central Alaska Range, Alaska: American Geophysical Union Chapman Conference on Active Tectonics and Seismic Potential of Alaska, 11-14 May, Alyeska Resort, Girdwood, Alaska, poster session presentation.

Doser, D., 2004, Seismicity of the Denali-Totschunda fault zone in central Alaska (1912-1988) and its relation to the 2002 Denali Fault Earthquake Sequence; in Rowe, C.A., Christensen, D., and Carver, G.A., eds., The 2002 Denali Fault Earthquake Sequence, Dedicated Issue: Bulletin of the Seismological Society of America, v. 94, no. 6B, p. S132-S144.

Eberhart-Phillips, D., Haeussler, P.J., Freymueller, J.T., Frankel, A.D., Rubin, C.M., Craw, P.A.C., Ratchkovski, N.A., Anderson, G., Carver, G.A., Crone, A.J., Dawson, T.E., Fletcher, H., Hansen, R, Harp, E.L., Harris, RA., Hill, D.P., Hreinsdottir, S., Jibson, RW., Jones, L.M., Kayen, R, Keefer, D.K., Larsen, C.F., Moran, S.C., Personius, S.C., Plafker, G., Sherrod, B., Sieh, K., Sitar, N., and Wallace, W.K., 2003, The 2002 Denali fault earthquake, Alaska; A large magnitude, slip partitioned event: Science, v. 300, p. 1,113-1,118.

Holmes, G.W., 1965, Geologic reconnaissance along the Alaska Highway, Delta River to Tok Junction, Alaska: United States Geological Survey Bulletin 1181-H, 19 p., 1 sheet, scale 1:125,000.

Holmes, G.W., and Foster, H.L., 1968, Geology of the Johnson River area, Alaska: United States Geological Survey Bulletin 1249, 49 p., 1 sheet, scale 1:63,360.

Lacelle, Denis, Lauriol, Bernard, Clark, I.D., Cardyn, Raphaelle, and Zdanowicz, Christian, 2007, Nature and origin of a Pleistocene massive ground-ice body exposed in the Chapman Lake moraine complex, central Yukon Territory, Canada: Quaternary Research, v. 68, no. 2, p. 249-260.

Lerbekmo, J.F., Westgate, J.A., Smith, D.G.W., and Denton, G.H., 1975, New data on the character and history of the White River volcanic eruption, Alaska, in Suggate, R.P., and Cresswell, M.M., eds., Quaternary studies: Wellington, New Zealand, The Royal Society of New Zealand, p. 203-209.

Lesh, M.E., and Ridgeway, K.D., 2007, Geomorphic evidence of active transpressional deformation in the Tanana foreland basin, south-central Alaska, in Ridgeway, K.D., Trop, J.M., Glen, M.G., and O’Neill, J.M., eds., Tectonic growth of a collisional continental margin; Crustal evolution of southern Alaska: Geological Society of America Special Paper 431, p. 573-592.

Matmon, A., Schwartz, D.P., Haeussler, P.J., Finkel, R., Lienkaemper, J.J., Stenner, H.D., and Dawson, T.E., 2006, Denali fault slip rates and Holocene-late Pleistocene kinematics of central Alaska: Geology, v. 34, no. 8, p. 645-648.

Muhs, D.R., Ager, T.A., Betis, E.A., III, McGeehin, John, Been, J.M., Begét, J.E., Pavich, M.J., Stafford, T.W., Jr., and Stevens, D.S.P., 2003, Stratigraphy and palaeoclimatic significance of late Quaternary loess-paleosol sequences of the late interglacial-glacial cycle in central Alaska: Quaternary Science Reviews, v. 22, p. $1,947-1,986$.

Page, R.A., Plafker, G., and Pulpan, H., 1995, Block rotation in east-central Alaska; A framework for evaluating earthquake potential?: Geology, v. 23, no. 7, p. 629-632.

Péwé, T.L., and Holmes, G.W., 1964, Geology of the Mount Hayes D-4 quadrangle, Alaska: United States Geological Survey Miscellaneous Geologic Investigations Map I-394, scale 1:63,360, 2 sheets.

Péwé, T.L., and Reger, R.D., 1983, Delta River area, Alaska Range; in Péwé, T.L. and Reger, R.D., eds., Guidebook to permafrost and Quaternary geology along the Richardson and Glenn Highways between Fairbanks and Anchorage, Alaska: Alaska Division of Geological \& Geophysical Surveys Guidebook 1, p. 47-135.

Péwé, T.L. and others, 1953, Tentative correlation of glaciations in Alaska; in Péwé, T.L. and others, Multiple glaciations in Alaska: United States Geological Survey Circular 289, p. 12-13.

Plafker, George, Gilpin, L.M., and Lahr, J.C., 1994, Neotectonic Map of Alaska, in Plafker, George, and Berg, H.C., eds., The Geology of Alaska: Boulder, Colorado, Geological Society of America, Geology of North America, v. G-l, 12 plates, scale $1: 2,500,000$.

Reger, R.D., and Péwé, T.L., 2002, Geologic map of the Big Delta A-4 Quadrangle, Alaska: Alaska Division of Geological \& Geophysical Surveys Report of Investigations 2002-2, 1 sheet, scale 1: 63,360. 
Reger, R.D., Stevens, D.S.P., and Solie, D.N., 2008a, Evidence of multiple outburst floods, upper Tanana River valley, eastcentral Alaska: Geological Society of America Abstracts with Programs, v. 40, no. 1, p. 36.

2008b, Surficial-geologic map of the Alaska Highway corridor, Delta Junction to Dot Lake, Alaska: Alaska Division of Geological \& Geophysical Surveys Preliminary Interpretive Report PIR 2008-3a, 2 sheets, scale 1:63,360, in press.

Reimer, P., Baillie, M.G.L., Bard, E., Bayliss, A., Beck, J.W., Bertrand, J.H., Blackwell, P.G., Buck, C.E., Burr, G.S., Cutler, K.B., Damon, P.E., Edwards, R.L., Fairbanks, R.G., Friedrich, M., Guilderson, T.P., Hogg, A.G., Hughen, K.A., Kromer, B., McCormac, G., Manning, S., Bronk Ramsey, C., Reimer, R.W., Remmele, S., Southon, J.R., Stuiver, M., Talamo, S., Taylor, F.W., van der Plicht, J., and Weyhenmeyer C.E., 2004, IntCa104 terrestrial radiocarbon age calibration, 0-26 cal kyr BP: Radiocarbon, v. 46, no. 3, p. 1,029-1,058.

Ridgway, K.D., Trop, J.M, Nokleberg, W.J., Davidson, C.M., and Eastham, K.R., 2002, Mesozoic and Cenozoic tectonics of the eastern and central Alaska Range; Progressive basin development and deformation in a suture zone: Geological Society of America Bulletin, v. 114, no. 12, p. 1,480-1,504.

Schmoll, H.R., 1984, Late Pleistocene morainal and glaciolacustrine geology in the upper Copper River-Mentasta Pass area, Alaska [abs.]: Geological Society of America Abstracts with Programs, v. 16, no. 6, p. 332.

Solie, D.N., and Burns, L.E., 2006, Geology, geophysics, and geohazards along the Alaska Highway corridor; A project of the Alaska Division of Geological \& Geophysical Surveys (poster): Yukon Geosciences Forum, November 2006, Whitehorse, Yukon Territory, Canada.

2007, Alaska Highway Corridor geology and geophysics: Alaska GeoSurvey News, Alaska Geological and Geophysical Surveys, no.10, p. 1.

Thorson, R.M., 1986, Late Cenozoic glaciation of the northern Nenana Valley, in Hamilton, T.D., and Thorson, R.M, eds., Glaciation in Alaska—the geologic record: Alaska Geological Society, p. 99-122.

Triplehorn, D.M., Drake, J., and Layer, P.W., 1999, Preliminary ${ }^{40} \mathrm{Ar} /{ }^{39} \mathrm{Ar}$ ages from two units of the Usibelli Group, Healy, Alaska; New light on some old problems: Alaska Division of Geological \& Geophysical Surveys Professional Report 119, p. 117-127.

Ward, B.C., Bond, J.D., and Gosse, J.C., 2007, Evidence for a 55-50 ka (early Wisconsin) glaciation of the Cordilleran ice sheet, Yukon Territory, Canada: Quaternary Research, v. 68, no. 1, p. 141-150.

Wahrhaftig, C., 1958, Quaternary geology of the Nenana River valley and adjacent parts of the Alaska Range: United States Geological Survey Professional Paper 293-A, p. 1-68.

Wahrhaftig, C., Wolfe, J.A., Leopold, E.B., and Lanphere, M.A., 1969, The coal-bearing group in the Nenana Coal Field, Alaska: United States Geological Survey Bulletin 963-E, 30 p.

Wells, D.L., and Coppersmith, K.J., 1994, Empirical relationships among magnitude, rupture length, rupture area, and surface displacement: Bulletin of the Seismological Society of America, v. 84, p. 974-1002.

Westgate, J.A., Preece, S.J., Froese, D.G., Pearce, N.J.G., Roberts, R.G., Demuro, M., Hart, W.K., and Perkins, W., 2008, Changing ideas on the identity and stratigraphic significance of the Sheep Creek tephra beds in Alaska and the Yukon Territory, northwestern North America: Quaternary International, v. 178, no. 1, p. 183-209.

Young, N.E., Briner, J.P., Kaufman, D.S., and Finkel, R.C., 2007, 10Be ages from northern Alaska Range moraines help constrain the timing of the penultimate glaciation in eastern Beringia: EOS Transactions, v. 88, no. 52, Fall Meeting Supplement Abstract PP33B-1275. 


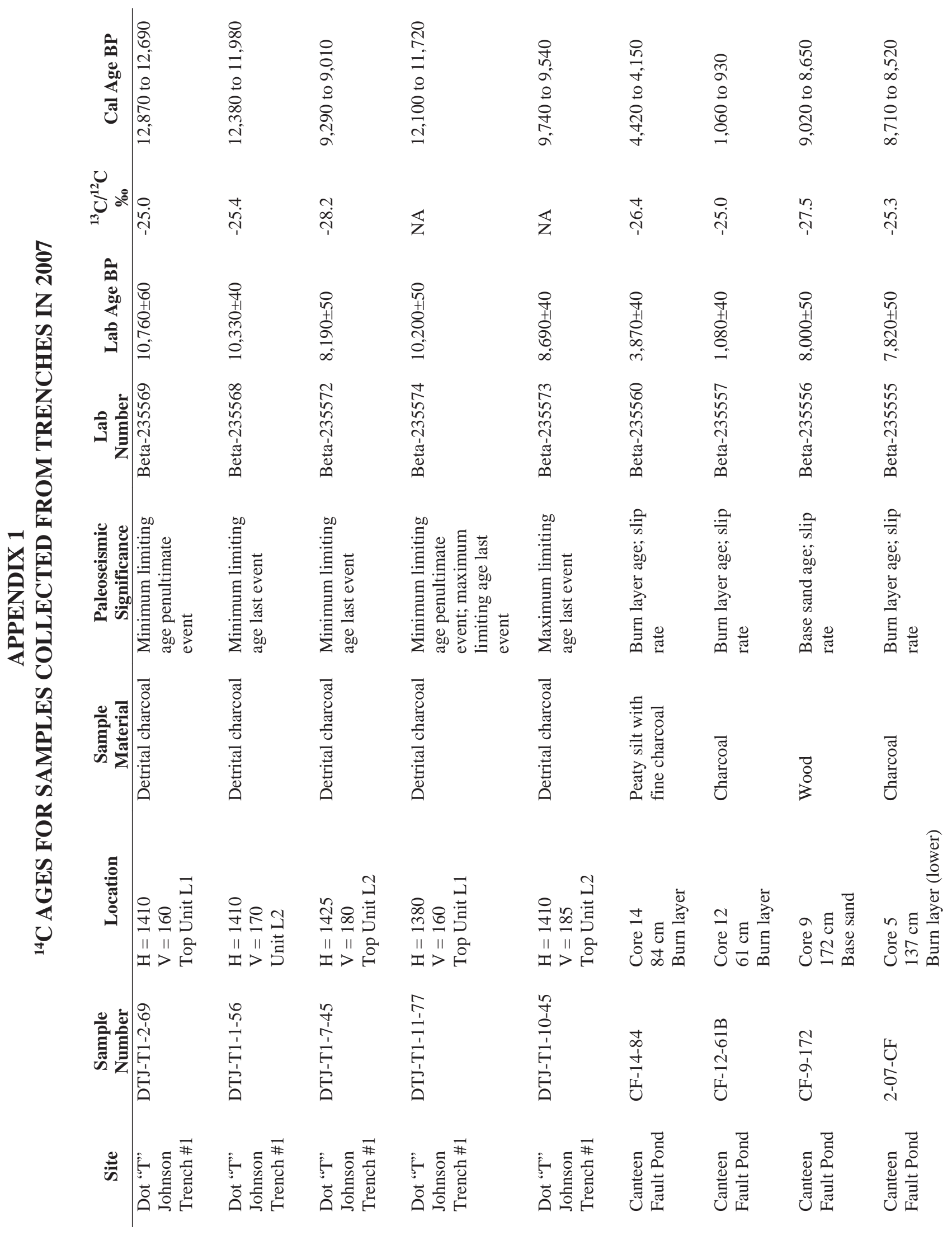




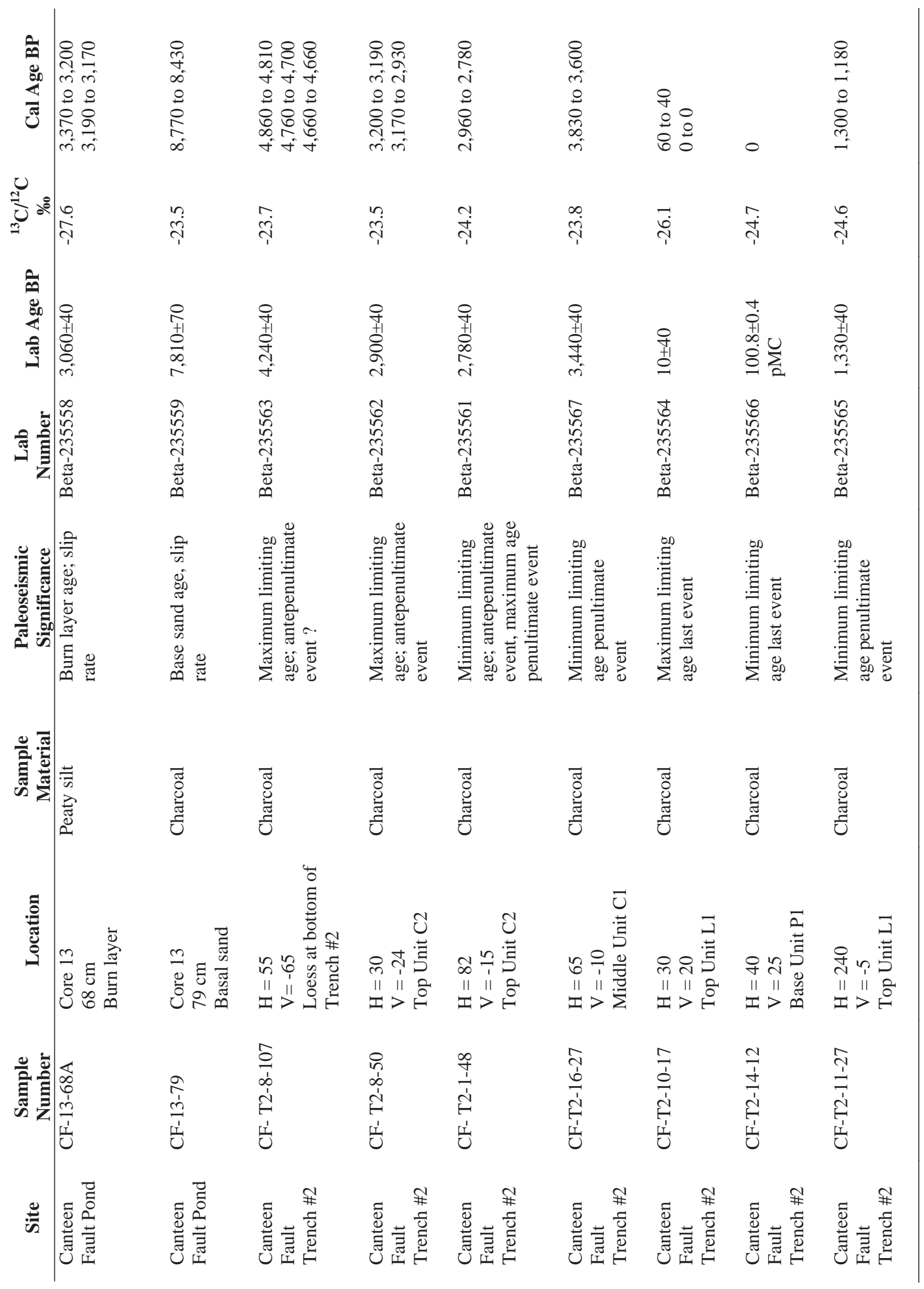

